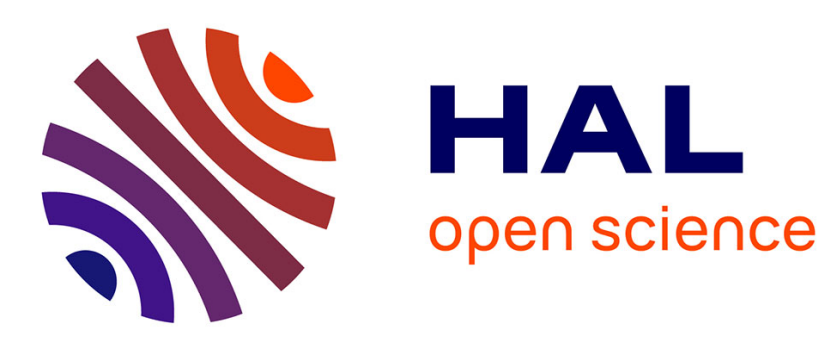

\title{
A quantification of the glacial imprint on relief development in the French western Alps
}

Peter van Der Beek, P. Bourbon

\section{To cite this version:}

Peter van Der Beek, P. Bourbon. A quantification of the glacial imprint on relief development in the French western Alps. Geomorphology, 2008, 97 (1-2), pp.52 à 72. 10.1016/j.geomorph.2007.02.038 . insu-00351301

\section{HAL Id: insu-00351301 https://hal-insu.archives-ouvertes.fr/insu-00351301}

Submitted on 12 Jan 2009

HAL is a multi-disciplinary open access archive for the deposit and dissemination of scientific research documents, whether they are published or not. The documents may come from teaching and research institutions in France or abroad, or from public or private research centers.
L'archive ouverte pluridisciplinaire HAL, est destinée au dépôt et à la diffusion de documents scientifiques de niveau recherche, publiés ou non, émanant des établissements d'enseignement et de recherche français ou étrangers, des laboratoires publics ou privés. 


\title{
A Quantification of the Glacial Imprint on Relief Development in the French Western Alps
}

\author{
Peter van der Beek and Pierre Bourbon \\ Laboratoire de Géodynamique des Chaînes Alpines, Université Joseph Fourier, \\ BP 53, 38041 Grenoble Cedex, France
}

Geomorphology, 97, 52-72

Special Issue: “Glacial landscape evolution:

implications for glacial processes, patterns and reconstructions"

D.A. Swift and A.P. Stroeven, editors

submitted: 02 October 2006

revised: 22 December 2006

accepted: 05 January 2007

\section{Corresponding author:}

P.A. van der Beek

Laboratoire de Géodynamique des Chaînes Alpines,

Université Joseph Fourier,

BP 53, 38041 Grenoble Cedex,

France

Phone: +33476 514062

Fax: $\quad+33476514058$

Mail: pvdbeek@ujf-grenoble.fr 


\section{Abstract}

The morphology of the western Alps has been strongly influenced by Quaternary glaciations. On the basis of observations of glacial morphology in the Belledonne, Grandes-Rousses, Taillefer and Pelvoux-Ecrins Massifs (south-eastern France), we reconstitute the glacial trimline and equilibrium line altitude (ELA) during the most extensive glaciation (MEG). Our best estimate of the MEG ELA is $1800 \pm 100 \mathrm{~m}$. Using digital elevation models, we compare our glacial reconstruction with the relief structure of 9 major catchments draining the massifs. Modal elevations of the largest catchments occur at 2000-2500 $\mathrm{m}$ and coincide with minima in plots of mean slope angles as a function of elevation. Modal elevations and slope minima occur between the modern and MEG ELA's, confirming a strong glacial imprint on relief. In order to quantify glacial valley carving in the massifs, we isolated high-elevation, low-relief surfaces that form rock shoulders adjacent to the glacial valleys from a Digital Elevation Model and constructed an interpolated surface passing through these. Subtracting the presentday topography from this surface allows us to quantify the maximum glacial-valley depths. Maximum valley depths determined in this manner are typically $>1000 \mathrm{~m}$, with spatial maxima occurring around the location of the MEG ELA in most valleys. These numbers do not take into account glacial valley widening local glacial overdeepenings but also neglect potential pre-glacial fluvial valley incision, which could account for $20-50 \%$ of the measured valley depths. The inferred valley depths are, however, reasonably well correlated with the mean reconstructed ice thickness, and constitute about half of the sub-ridgeline relief of the studied catchments. These results lead us to propose a significant Quaternary increase in the relief of the French western Alps, controlled by climate and associated with the initiation of alpine glaciations. For reasonable values of the effective elastic thickness of the lithosphere, the isostatic response to glacial valley carving reaches values of $\sim 300 \mathrm{~m}$ across the massifs. This number is insufficient to substantially offset topographic lowering due to regional denudation, and we conclude that the isostatic response to glacial valley carving has not increased peak elevations significantly.

Keywords: Alps, glacial erosion, relief development, isostatic rebound, hypsometry, slope distribution 


\section{Introduction}

The interaction between tectonics, climate and the topography of mountain belts has been a key issue in geodynamics over the last 15 years, since Molnar and England (1990) suggested that late-Cenozoic climatic forcing, in particular the rapid succession of glacial and interglacial conditions, has led to increased erosion of mountain belts and consequent isostatic uplift of their peaks. A late Cenozoic increase in sedimentation rates has been documented in sedimentary basins occurring in widely varying tectonic settings around the world, suggesting that the associated increase in erosional flux is climatically controlled (Kuhlemann et al., 2002; Métivier et al., 1999; Molnar, 2004; Zhang et al., 2001). A contrasting view has, however, been expressed by Raymo and Ruddiman (1992), who suggested that, rather than resulting from it, increased uplift and erosion rates control late-Cenozoic climate change through increased atmospheric $\mathrm{CO}_{2}$ drawdown by weathering reactions.

Many of the world's mountain belts have been extensively glaciated during Quaternary times, and glacial conditions have prevailed in them for most of the time since the onset of major glaciations. Thus, glacial erosion has been the predominant erosional mechanism affecting these mountain belts over the last few million years. Recent studies on long-term exhumation rates in Alaska and British Columbia (Shuster et al., 2005; Spotila et al., 2004) suggest a strong coupling between glaciation and denudation. Thus, late Cenozoic glaciations and the associated expansion of glacial cover could have strongly influenced the morphology of mountain belts. Resolving the controversy regarding the feedback between late Cenozoic climate change and tectonics therefore requires quantitative data on the relative efficiencies of glacial versus fluvial erosion in a wide range of geomorphic settings (e.g., Brocklehurst and Whipple, 2002; Montgomery, 2002; Whipple et al., 1999), as well as on the impact of glaciation on relief development in mountain belts (e.g., Brozovic et al., 1997; Stern et al., 2005; Tomkin and Braun, 2002).

A rapid and powerful way to quantitatively assess morphology is through hypsometric analyses of topography using Digitial Elevation Models (DEM's). A glacial imprint on relief manifests itself through the development of more concave valley long profiles by cirqueheadwall retreat, and the widening of valleys into characteristic U-shaped troughs (Anderson et al., 2006; Kirkbride and Matthews, 1997). Both these effects tend to increase the relative frequency of elevations where glacial erosion is efficient (Brocklehurst and Whipple, 2003). 
Brozovic et al. (1997), for instance, showed that the mean elevation as well as $50 \%$ of the total area of several massifs in the NW Himalaya, characterised by widely varying uplift and exhumation rates, lie between the present-day and Last Glacial Maximum (LGM) Equilibrium Line Altitudes (ELA). They also showed that this elevation range coincides with a distinct minimum in mean slope values and concluded that (1) the morphology of these massifs is controlled primarily by the position of the mean ELA through time, and (2) glacial erosion rates at these altitudes could counteract even the highest tectonic uplift rates. This result is consistent with the theoretical expectation that the erosive capacity of glaciers increases with their basal sliding velocity (Andrews, 1972; Hallet, 1979; 1996; Humphrey and Raymond, 1994), which reaches maximum values at the ELA (e.g., Anderson et al., 2006 and references therein). Glacial erosion should thus be particularly efficient within the range of elevations comprising the ELA through time (Anderson et al., 2006; Meigs and Sauber, 2000).

Another issue involves the isostatic response to glacial erosion. Several authors have argued that major valley incision may lead to uplift of mountain peaks, as the isostatic response to erosion takes places on spatial scales of 10's to 100's of km, depending on the flexural rigidity of the lithosphere (Molnar and England, 1990; Montgomery, 1994; Small and Anderson, 1995; 1998; Stern et al., 2005). The efficiency of this mechanism depends on the spatial distribution of erosion, as the regional isostatic response to valley carving should outstrip erosion on the peaks in order to produce local surface uplift (Montgomery, 1994; Small and Anderson, 1998). Whether this is the case, particularly in response to the glaciation of mountain ranges, is unclear at present.

Many of the studies aimed at quantifying the link between glaciation, denudation, and relief development have focused on either very rapidly uplifting and eroding mountain belts such as southern Alaska, the northwest Himalaya or the southern Alps of New Zealand (e.g., Brook et al., 2006; Brozovic et al., 1997; Kirkbride and Matthews, 1997; Meigs and Sauber, 2000), or on slowly eroding post-orogenic topography such as in the Sierra Nevada (California) or Sangre de Cristo (Colorado) ranges (Brocklehurst and Whipple, 2002; 2003). Here, we set out to quantify these relationships in the western European Alps, which have constituted a classical example for the glacial influence on relief development for over a century (e.g., de Martonne, 1910-1911; Penck and Brückner, 1901-1909; Tricart and Cailleux, 1962) and are characterised by limited tectonic activity but a strong glacial influence during Quaternary times. Continuous GPS measurements show that present-day convergence rates in the western 
and central Alps are close to zero (Calais et al., 2002), in stark contrast to geodetically determined rock uplift rates, which locally reach values $>1 \mathrm{~mm} / \mathrm{y}$ (Jouanne et al., 1995; Kahle et al., 1997). Not more than $1 / 3$ to $1 / 2$ of present-day rock uplift rates can be attributed to post-glacial rebound (Gudmundsson, 1994; Stocchi et al., 2005); the question to what extent isostatic response to glacial erosion of the belt contributes to present-day rock uplift is thus clearly posed.

In this paper, we first aim to reconstruct the maximum glacial cover during Quaternary times and to quantify the glacial imprint on the morphology of part of the French western Alps, using DEM analyses as our principal tool. We then estimate the amount of glacial relief production through valley carving. Finally, we assess whether the isostatic response to this differential erosion may have significantly affected peak uplift. We focus on the PelvouxEcrins, Grandes Rousses and Belledonne massifs of south-eastern France (Figure 1), where abundant geomorphic markers such as cirques, valley steps and hanging valleys clearly indicate the major imprint of glacial erosion on the present-day morphology (e.g., Montjuvent, 1974; 1978).

\section{Geological and Geomorphic Setting}

The "external crystalline massifs" of the western and central Alps consist of blocks of European crystalline basement that were exhumed along crustal-scale thrusts since Oligocene - Early Miocene times (Leloup et al., 2005; Schmid and Kissling, 2000). These massifs are characterised by some of the highest topography and relief of the Alpine orogen and concentrate most of it's $>4000 \mathrm{~m}$ high peaks. Low-temperature thermochronology data indicate that the external crystalline massifs have undergone $\mathrm{km}$-scale denudation since Late Pliocene times (3-5 Ma; e.g., Bigot-Cormier et al., 2000; Leloup et al., 2005; Michalski and Soom, 1990) and they are also the site of rapid present-day rock uplift (up to $1 \mathrm{~mm} / \mathrm{y}$; Jouanne et al., 1995; Kahle et al., 1997).

Here we focus on the westernmost external crystalline massifs, comprising the Belledonne, Taillefer, Grandes Rousses and Pelvoux-Ecrins massifs (Figure 1). These are made up of several basement blocks with intervening remnants of inverted Jurassic extensional basins. 
Basement blocks have been thrust up along steeply dipping faults with variable strikes, which result from a complex polyphase history during both Early Jurassic rifting and Tertiary Alpine convergence phases that affected the region (Dumont et al., in press; Ford, 1996). The relatively complex drainage pattern within the massifs is partly controlled by this structural grain. The massifs are bordered to the north and west by the "subalpine" Chartreuse and Vercors massifs, built up of Mesozoic calcareous sedimentary sequences. The limit between the basement and subalpine massifs in the western Alps is generally marked by major valleys that are known as the "subalpine trough" (sillon subalpin) to French geologists. In the study area, the northern limit between the Belledonne and Chartreuse massifs is formed by the Isère (or Grésivaudan) valley, whereas to the west the limit between the Taillefer/Pelvoux-Ecrins and Vercors massifs is formed by the Drac valley. The Grésivaudan valley was occupied by a major alpine glacier (the Isère glacier) during glacial times, which has overdeepened the valley down to several $100 \mathrm{~m}$ below sea-level (Gidon, 1992; Montjuvent and Winistorfer, 1980). The Drac valley, in contrast, was only occupied by a through-going glacier during the most extensive glaciations, but was more generally dammed by the Isère and Romanche glaciers, leading to large-scale fluvial aggradation during glacial times (Brocard et al., 2003; Montjuvent, 1978). To the northeast and southeast, the Pelvoux-Ecrins massif is bordered by the Maurienne and Durance valleys, respectively, which overlie the tectonic contact between external and internal Alps (the Penninic thrust) and also hosted major alpine glaciers during glacial times.

The wide valleys surrounding the western alpine massifs contrast strongly with the deep and narrow valleys that occur within the massifs (Figures 1 and 2). Valley long profiles within the massifs present a succession of valley steps and flats, characteristic of glacially perturbed fluvial profiles. Both hanging valleys (at the confluences of small tributary valleys with a main throughgoing valley) and overdeepened troughs, downstream of the confluences of equally sized streams, are numerous; their occurrence is consistent with a glacial erosion model that links confluence steps and valley overdeepenings to the relative erosive power of the joining glaciers (Anderson et al., 2006; MacGregor et al., 2000). The most spectacular example of such a glacial overdeepening is the Bourg d'Oisans trough just downstream of the confluence of the Vénéon and Romanche valleys (Figure 2a), which has been filled by postglacial lake sediments (Bailly-Maître et al., 1997). In contrast to the strong glacial influence on long profile forms, the planform drainage pattern of the massifs is demonstrably pre- 
glacial, as indicated by the provenance of Miocene fluvial deposits in the subalpine chains and the foreland (Montjuvent, 1978).

A slope map of the study area (Figure 3) shows that valley bottoms are characterised by very low slopes and are bordered by steep and abrupt sidewalls. Lithology affects the slope distributions (Figure 4): modal slope values are generally steeper in basement rocks than in the sedimentary cover and the steepest gorge sidewalls occur in basement rocks. This is especially clear for granites, amphibolites and meta-conglomerates, which make up most of the Pelvoux-Ecrins, eastern Belledonne, and Taillefer massifs, respectively. Chloritic schists that characterise the western Belledonne Massif have intermediate slope values that are comparable to some of the sedimentary cover units. Irrespective of lithology, however, widespread low-relief plateau areas are encountered at elevations above $\sim 2000 \mathrm{~m}$, (Figures 2 and 3); these are developed both on Mesozoic sediments and on basement rocks. Many of these plateau areas show widespread evidence for glacial erosion and have developed close to the basement-cover interface (e.g., Battiau-Queney, 1997).

For our morphological analysis, we have divided the study area into its major drainage basins (cf. Figure 1). We consider six large catchments (Upper Romanche, Vénéon, Eau d'Olle, Bonne, Séveraisse, Upper Drac) draining the Pelvoux-Ecrins, Grandes Rousses and Belledonne massifs, as well as three smaller catchments in the Grandes Rousses (Sarenne), Taillefer (Lignarre) and western Pelvoux (Séveraissette) massifs. Table 1 lists the catchment areas and hypsometries for these drainage basins. The upper Romanche, Vénéon, Sarenne, Lignarre and Eau d'Olle rivers all drain into the Bourg d'Oisans plain, the outlet of which is formed by the lower Romanche River. After traversing a deep and narrow gorge between the Belledonne and Taillefer massifs, the latter joins the Drac River just south of Grenoble. The Bonne, Séveraisse and Séveraisette rivers drain the western part of the Pelvoux-Ecrins and Taillefer massifs and drain into the Drac River. We have excluded the eastern part of the Pelvoux-Ecrins massif, which is drained by tributaries of the Durance River, from our analysis because we are not able to reconstruct the glacial trimline with sufficient detail in this area (cf. next section). 


\section{Reconstructing ice cover}

Present-day perennial ice cover in the area is limited to a total area of $\sim 25 \mathrm{~km}^{2}$ around the highest peaks of the Pelvoux-Ecrins massif. We have reconstructed the glacial cover during peak glacial times using a database of glacially eroded landforms and glacial deposits. In particular, we use a detailed database collected by Beaudevin (2000) and augmented by our personal observations.

Several morphological features can be used to estimate the maximum elevation reached by glaciers. A glacial trimline is locally visible along the mountain flanks, separating lower slopes with clear glacial erosion features (roches moutonnées; striated or polished surfaces) from much more rugged upper slopes that show evidence for freeze-thaw rather than glacial erosion. Lateral moraines are locally present on rock shoulders at elevations below $2500 \mathrm{~m}$. On low-slope areas such as rock shoulders or glacially-breached divides, characteristic glacial grooves or troughs are widespread (Beaudevin, 2000). These may be either purely erosional features, or be associated with drumlin-like elongated hills composed of glacial deposits. The maximum elevation of these morphologic features (except for the moraines) at any location indicates the limit of sufficient ice cover to produce them, rather than the maximum ice surface itself. Each feature is characterised by a threshold ice thickness required to produce it, which is generally not well known. By comparing the elevations of lateral moraines and nearby glacial erosion features, Beaudevin (2000) has estimated these ice thicknesses and established some rules of thumb for reconstructing the ice surface elevation, which we follow here: (1) the ice surface follows the summits of lateral moraines; (2) it passes $100 \mathrm{~m}$ above the highest glacial erosion grooves on rock shoulders; (3) it passes $50 \mathrm{~m}$ above glacial grooves associated with drumlin-like features and (4) several tens of $\mathrm{m}$ above the summit of roches moutonnées.

A major problem in reconstructing the glacial cover is the age of the glacial features. Relatively detailed correlations and chronologies have been established for the frontal moraine systems of the major valley glaciers that extended into the Alpine foreland (e.g., Rhone glacier: de Beaulieu and Reille, 1984; Isère glacier: Gidon, 1992; Durance glacier: Jorda et al., 2000), but none of the glacial erosion features within the western alpine ECM 
have been dated. A widespread supposition is that most of these features date from the LGM, i.e. 20-25 ka BP in the Alps (Schlüchter, 1988), as they would have been erased by successive glaciations. However, it is clear from the frontal moraine record that more extensive glaciations than the LGM took place during Oxygen Isotope Stages 6 - 8, i.e. between 145 and $230 \mathrm{ka} \mathrm{BP}$ (Schlüchter, 1986). These are known as the Most Extensive Glaciation (MEG). Finally, there is controversy about the relative extent of glaciation during Oxygen Isotope Stage 4 ( $\sim 60$ ka BP) with respect to the LGM (Brocard, 2002; Guiter et al., 2005; Schoeneich, 1998). Beaudevin (2000) used a theoretical model (e.g., Lliboutry, 1964) to extrapolate glacier elevations from the dated terminal moraines and to discriminate LGM from MEG glacial features. However, since this model is not well adapted to narrow valley glaciers, the results of this exercise are inconclusive. Here, we will use the highest glacial features encountered at any location to reconstruct a maximum glacial extent within the study area, which we associate to the MEG.

Figure 5 shows the distribution and elevation of geomorphic features used to reconstruct the maximum glacial cover of the study area. The geomorphic markers are concentrated in the areas of basement rock outcrop, as these lithologies are more difficult to erode and preserve glacial features better than the Mesozoic calcareous sediments. For this reason, there is a relative paucity of glacial trimline markers in the subalpine massifs. The easily erodible lithologies (mainly calc-schists) of the internal alpine zones east of the Durance Valley lack clear trimline markers for the same reason. Nevertheless, the elevation pattern of the trimline markers is consistent and indicates a dome-like shape for the ice cover, centred on the highest peaks of the Pelvoux-Ecrins Massif that are still glaciated at present.

Studies on the LGM ice cover in the Swiss Alps have long described the glacial paleogeography as a network of independent valley glacier (e.g., Haeberli and Penz, 1985). More recent studies, however, have shown that the glacial cover was more like an ice cap or dome permitting glacial flow that was relatively independent of the pre-existing fluvial valleys (Florineth and Schlüchter, 1998; Kelly et al., 2004). We suggest a similar glacial paleogeography for the western Alpine massifs studied here as field evidence for breached divides is common within the area (Beaudevin, 2000; Montjuvent, 1974), with only the highest peaks surmounting the ice surface as nunataks. 
We have thus interpolated the data in Figure 5 using a continuous curvature spline algorithm with a tension factor of 0.25 (Smith and Wessel, 1990) in order to obtain a smooth surface, which represents the active ice-surface of the main valley glaciers; smaller cirque glaciers are not systematically taken into account by this analysis. Comparing this surface with the present-day topography (50-m resolution DEM) allows visualising the inferred extent of active ice cover and ice thickness during the MEG (Figure 6). Note that the ice thickness reconstructed in this manner is necessarily a model approximation, since it uses the presentday topography as a reference instead of the (unknown) topography present during the MEG.

The elevation contours of the reconstructed ice surface (Figure 6a) can be used as first-order indicators of glacial flow, which would be directed orthogonally to them along the surface gradient. Elevation contours of the ice surface are generally perpendicular to the valley axes within the studied massifs, suggesting glacier flow parallel to these valleys as expected. This correlation breaks down, however, within the large glacial valleys surrounding the massifs (Drac, Grésivaudan, Maurienne, Durance), suggesting that the reconstructed ice-surface contains artefacts in these areas, because of the lack of trimline indicators outside of the basement massifs. We will, therefore, concentrate on the glacial imprint on the morphology in the interior of the massifs.

\section{Estimating the minimum ELA}

From the reconstructed ice cover, we can attempt to estimate the position of the Equilibrium Line Altitude (ELA) associated with the MEG. The present-day ELA of glaciers within these massifs is well constrained at $\sim 2900 \mathrm{~m}$ above sea level; several glaciers having been monitored over the last decades (Rabatel et al., 2005; Vincent, 2002). In order to estimate the MEG ELA, we will use the classical Toe to Headwall Altitude Ratio (THAR) and Accumulation Area Ratio (AAR) methods (e.g., Porter, 2000 and references therein). The THAR method uses the maximum and minimum elevations reached by the glaciers, as indicated by the highest glacial cirques and the frontal moraines, respectively, and estimates the ELA by comparison to modern glaciers. Most authors suggest THAR values of around 0.5 for large valley glaciers, i.e., the ELA is approximately at mid-elevation between the glacier summit and its front. The AAR method is based on the relative size of the accumulation area 
of the glaciers with respect to their total area. Typical AAR values for modern glaciers are of the order of 0.65 (Porter, 2000), i.e., $\sim 2 / 3$ of the glacier area is above the ELA. The AAR method is generally considered more reliable because it takes into account the hypsometry of the glaciers; it requires, however, a more detailed knowledge of the glacial paleogeography. Note that, since the ELA is affected by microclimate and local topography, most mountain belts show regional gradients in ELA. However, since we are focussing on a relatively small area, in which there are no indications for significant variations in present-day ELA, we will ignore possible ELA gradients here.

Using the THAR method, we infer a MEG ELA at $1750 \pm 100 \mathrm{~m}$ for the area (weighted mean and standard deviation of the values inferred for the individual drainage basins, cf. Table 1). As the glaciers filling these valleys were all interconnected during the MEG and joined the Isère glacier at Grenoble, we have taken a common minimum altitude of $200 \mathrm{~m}$ (the elevation of the MEG terminal moraines in the Isère valley) to calculate the ELA. We have combined this with the maximum elevation of the ice surface within each drainage basin and a THAR value of 0.5 to obtain this estimate.

Using the AAR method, we can only estimate an ELA for the entire area as all the glaciers are interconnected and the accumulation and ablation areas are thus not independent. The ELA estimated in this way is conspicuously low $(\sim 1400 \mathrm{~m})$, implying ELA lowering that much exceeds commonly accepted values of about $1000 \mathrm{~m}$ during glacial times (e.g., Coutterand and Nicoud, 2005; Ivy-Ochs et al., 2004). This discrepancy may result from both model artefacts and an overestimation of the AAR value used. As explained above, the reconstruction of the glacial surface is not satisfactory in the major valleys surrounding the studied massifs; these valleys constitute an important part of the glacial surface taken into account for the ELA estimation and ice surface elevations may be underestimated there. Also, some of the high-elevation cirque glaciers have not been taken into account in the reconstruction, and the limits of glacial drainage basins taken into account in this estimate are relatively arbitrary. For instance, we have cut off the Isère glacier because we have not reconstructed its very large glacial catchment that extends to the northeast of our study area. Finally, the AAR value may be overestimated because of the influence of possible debris cover, which may strongly reduce ablation rates if it is sufficiently thick (Benn and Lehmkuhl, 2000). In the presence of significant debris cover, the THAR may reach values of $0.6-0.8$, while the AAR would be reduced to values $0.1-0.4$ (Clark et al., 1994). 
A straightforward but labour-intensive method of estimating the minimum ELA attained during glaciations is to map out the minimum elevations of glacial cirques, under the hypothesis that glaciers do not have sufficient erosive power to carve out such features below the ELA. Within the studied massifs, cirques are encountered at elevations above $1900 \mathrm{~m}$ (Montjuvent, 1974; 1978). This method is rather coarse and tends to overestimate the ELA values for valley glaciers (Porter, 2000; Ramage et al., 2005), thus providing a maximum elevation for the MEG ELA. Taking all of the above considerations in mind, we estimate the MEG ELA as being situated at $1800 \pm 100 \mathrm{~m}$. The position of this inferred ELA is indicated in Figure $6 \mathrm{~b}$. A comparison with the model ice thickness, obtained by subtracting the presentday topography from the interpolated MEG ice surface, shows that the inferred ELA occurs just downstream of the largest ice thicknesses in the valleys occurring within the massif, lending support to our estimate.

\section{Present-day relief and relation with former ice cover}

In order to document the glacial imprint on the topography, we quantify the relief structure of the different drainage basins studied. Figure 7 shows the hypsometries (i.e. the frequency distribution of altitudes) of these catchments, as well as the altitudinal dependence of slopes (i.e., the mean slope values for each 100-m elevation interval in each drainage basin). The analysis shows that a large proportion of the catchment areas $(61 \%$ on average, with values ranging between $42 \%$ (Lignarre) and $78 \%$ (Upper Drac) for individual catchments), lies between the reconstructed MEG ELA at $1800 \pm 100 \mathrm{~m}$ and the present-day ELA at $2900 \mathrm{~m}$ above sea level, whereas this elevation range represents on average only $41 \%$ of the total elevation range of the catchments. Modal elevations for all large catchments, except the Bonne, also lie within the elevation range 1900-2900 m, in general (except for the Vénéon catchment) toward the lower end of this interval. Moreover, mean slope values show a local minimum within the same elevation range (Figure 7). This is particularly clear for the largest catchments (i.e. Séveraisse, Upper Drac, Upper Romanche, Vénéon). The large Bonne catchment is a particular case, because it includes most of the Matheysine plateau, a very lowgradient glacial valley at $\sim 1000 \mathrm{~m}$ elevation carved by a southward flowing divergent branch of the Romanche glacier (cf. Figures 1 and 3). This plateau shows up as a peak around 1000 $\mathrm{m}$ in the Bonne hypsometry, associated with very low slope values. 
The relief structure and slope distributions of these Alpine catchments is thus very similar to that described by Brozovic et al. (1997) for a number of NW Himalayan massifs, even though their study pertained to a much larger spatial scale, and we interpret the results in the same way. Although there is a lithological control on the slope distributions in these massifs (Figure 4), there is no consistent altitudinal distribution of lithology so that we can rule out lithological variation as the main origin of the altitudinal variation in mean slope values. Instead, the apparent relationship between modal elevations, slope minima and the range of ELA through time, suggest a strong glacial imprint on the topography. In particular, effective glacial erosion at these elevations will lead to rapid headward erosion and cirque retreat, leaving a large proportion of the surface area at an elevation range close to the ELA (Brocklehurst and Whipple, 2003; Oskin and Burbank, 2005). Note that the elevations of the present-day (interglacial) and MEG ELA's can be interpreted as the upper and lower limits for the ELA throughout Quaternary times and the mean Quaternary ELA will be located within the interval defined by these elevations (e.g., Porter, 1989). Finally, it is important to note that, although the high-elevation, low-relief surfaces discussed in section 2 (cf. Figures 2 and 3) contribute to the hypsometric peaks and slope minima observed in Figure 7, their aerial extents are rather small. The glacial imprint on topography, although most clearly developed on these landscape elements, affects a much larger part of the topography.

\section{Assessing glacial erosion and rebound}

The relatively low-relief elevation range discussed above is deeply incised by major valleys (Figures 1-3) whose steep sidewalls show up as local maxima in the slope-elevation curves just below the minimum ELA (Figure 7). These valleys have thus been carved within the lowrelief surface around the ELA, to a large extent by valley glaciers. Here we attempt to estimate the amount of erosion that can be attributed to glacial valley carving, as well as the isostatic response to the associated crustal unloading. In order to do this, we will use a very simple approach, which is a variant of that initially proposed by Small and Anderson (1998; Figures 8,9 ). Given the observation that the glacial valleys are generally bordered by highelevation, low-relief rock shoulders, we attempt to extract these landscape elements from the DEM and interpolate the "missing area" between them in order to obtain a continuous surface that excludes the glacial valleys. Subtracting the present-day topography from this surface should give us an estimate of the glacial valley depths (Figure 8). This will provide an 
estimate of glacial relief production. Note that valley widening associated with the development of the high-elevation, low-relief surfaces (cf. previous section) is not taken into account with this method, as the low-relief surfaces are used as a reference to quantify glacial valley deepening.

Figure 9a shows the distribution of extracted high-elevation, low-relief surfaces. In order to exclude low-relief valley bottoms, we first applied a spatially variable minimum-elevation threshold to the DEM, varying linearly between $800 \mathrm{~m}$ at the edge of the study area and 2600 $\mathrm{m}$ at the location of the highest peaks of the Ecrins massif. We then applied a maximum-slope threshold of $0.3\left(\sim 17^{\circ}\right)$. Elevation and slope thresholds were varied by trial-and-error until a satisfactory extraction of surfaces was obtained. Inspection of Figure 9a shows that we capture the rock-shoulders occurring adjacent to glacial valleys well with this technique, while excluding all valley bottoms. Higher-elevation low-relief areas, that do not have a direct geomorphic significance, are also extracted with this technique, but do not influence our resulting estimate of valley depths. We construct a surface passing through these points using a continuous curvature spline algorithm with a tension factor of 0.5 . The resulting interpolated surface is confounded with the topography at high elevations but detaches itself from it across the major valleys (Figures 9c, d), such that the difference between this surface and the present-day topography provides an estimate of glacial valley depths.

The resulting glacial valley depths are generally $>1000 \mathrm{~m}$, reaching a maximum value of 1545 $\mathrm{m}$ occurring within the Bourg d'Oisans trough at the confluence of the Vénéon and Upper Romanche rivers. Note that the inferred valley depths provide a measure of total valley incision below the rock shoulders; since our analysis is purely geometrical we are not able to distinguish glacial valley carving from (pre-, sub- or post-glacial) fluvial incision.

There are several sources of potential error associated with this approach. First, the method does not account for glacial overdeepenings, which have been filled by lake sediments during Holocene times. Such overdeepenings may reach 200-300 $\mathrm{m}$ in the Bourg d'Oisans basin within the centre of the study area, whereas they reach up to 500-600 $\mathrm{m}$ in the Grésivaudan valley to the west. On the other hand, however, the interpolated surface minimises the depth of the pre-glacial valleys (cf. Figures $8,9 \mathrm{c}, \mathrm{d}$ ), whereas valley incision will be at least partly of pre-glacial fluvial origin. A potential method to estimate the importance of pre-glacial fluvial incision is to model river profiles based on stream-power models (Brocklehurst and 
Whipple, 2006). Brocard and van der Beek (2006) showed that rivers in non-glaciated catchments of the western Alps are well-described by a simple stream-power equation, such that river slope $S$ is a power-law function of contributing drainage area $A$ :

$$
S=k_{S} A^{-\theta}
$$

Brocard and van der Beek (2006) derived concavities $\theta$ of $0.36 \pm 0.09$ for these rivers, with steepness indices $k_{s}$ between 10 and 40 . Moreover, for catchment areas larger than $\sim 35 \mathrm{~km}^{2}$, rivers were shown to be transport-limited, such that their profiles are insensititive to bedrock lithology. We can thus estimate, to a first order, what the pre-glacial river profiles may have looked like. Figure 10 shows such a reconstruction for the Romanche River. It is based on equation (1), with $k=20 \mathrm{~m}^{0.72}$ and $\theta=0.36$. These values are chosen to be consistent with those inferred for non-glaciated catchments, while producing a profile that passes through both the confluence of the Isère and the Rhone Rivers downstream and the source of the Romanche River upstream. An independent constraint on the maximum slope and elevation of the downstream reach of the Isère River is given by the surface of the Chambaran Plateau, to the north of the study area, which has been constructed during Mio-Pliocene times by fluvial deposits of the Isère and Rhone Rivers (Chiron and Kerrien, 1979; Clauzon, 1990). As the Isère River flowed over this surface before its abandonment at $\sim 2 \mathrm{Ma}$, it provides a maximum elevation for the river at this time. The reconstructed river profile stays well below this surface (Figure 10). A comparison between the reconstructed river profile and the reconstructed surface used for assessing glacial incision shows that the reconstructed preglacial profile lies below this surface and indicates that part of the incision attributed to glacial valley carving may in fact be of pre-glacial fluvial origin. The estimated contribution of fluvial incision ranges between $\sim 20 \%$ in the upstream reaches of the Romanche river to as much as $50 \%$ downstream of the Bourg d'Oisans plain. Note, however, that our approach predicts minimum elevations for the pre-glacial profile (and thus maximum pre-glacial valley incision) as it excludes potential cirque lowering upstream and Quaternary fluvial incision downstream.

Finally, we stress that the interpolated surface does not constitute a paleosurface (or relict landscape) such that it could be used as an absolute marker of erosion, for two reasons. Firstly, we do not have chronological constraints on the formation of the low-relief rock shoulders so the reconstructed surface may well be diachronous. Secondly, whereas this method predicts no erosion of the highest parts of the topography, an apatite fission-track age- 
elevation profile at La Meije peak in the northern Pelvoux massif (location in Figure 1) provides evidence for regional denudation rates of $\sim 550 \pm 50 \mathrm{~m} / \mathrm{My}$ affecting these high elevations (van der Beek et al., manuscript in preparation). Thus, several tens to hundreds of meters of erosion have affected the region since the MEG; glacial valley carving has been superimposed on this regional denudation. The amount of erosion plotted in Figure $9 \mathrm{~b}$ should therefore not be considered an absolute amount, but the amount attributable to valley carving during glacial times, to which should be added the regional denudation.

Taking the above caveats into account, the inferred spatial pattern of valley depths gives us some confidence that we are capturing a glacial valley carving signal with this relatively simple method. Firstly, maximum valley depths within the studied massifs occur around the reconstructed position of the minimum ELA, as expected if valley carving is glacial in origin; this is particularly clear in the Bourg d'Oisans area (Romanche valley; Figure 9b). Secondly, we can test whether there is a relationship between the mean amount of glacial erosion in a catchment (quantified here as the sum of the valley depths at all points in a catchment divided by catchment area) and the maximum extent of glacial cover or ice thickness in that catchment (Table 1). Figure 11 shows that, while there is no clear correlation between the mean valley depths and the reconstructed relative ice cover, there is some correlation between valley carving and the reconstructed mean ice thickness (Pearson correlation coefficient $r^{2}=$ $0.33)$, which is clearest for the largest catchments $\left(r^{2}=0.39\right.$ when excluding the 3 smallest catchments). Note that the spatial patterns of ice thickness and valley depths look rather similar because both are calculated using the present-day topography as a reference. However, the two reconstructions are independent (based on trimline observations for the thickness and on DEM extraction of low-relief surfaces for the valley depths), as also indicated by the relatively weak correlation between them.

We have also verified whether there is a relationship between inferred valley carving and present-day relief. In order to quantify the geophysical relief (or "missing volume" beneath ridgelines and peaks) for each drainage basin, we calculated the sub-ridgeline relief as defined by Brocklehurst and Whipple (2002; cf. Table 1). In their method, an enveloping surface is constructed for each drainage basin by interpolating between the elevations of the catchment boundaries and present-day topography is subtracted from this surface to obtain the subridgeline relief. The mean sub-ridgeline relief is significantly larger than the mean valley depth (typically about twice as large), as expected, except for the three small catchments, 
where it is smaller. The reason for this discrepancy is that there are very few high-elevation, low-relief surfaces in these small catchments, which have been incised over nearly their total area. The amount of valley carving is reasonably well correlated with geophysical relief $\left(\mathrm{r}^{2}=\right.$ $0.53)$. When excluding the three smallest catchments, this correlation becomes very good $\left(\mathrm{r}^{2}=\right.$ 0.96), indicating that half of the sub-ridgeline relief in the studied area can be attributed to glacial valley carving.

Finally, we can estimate the amount of crustal unloading and isostatic response using the spatial variation of valley depths. Again, we stress that the rebound calculated here will be only that due to valley carving and will not be the total isostatic response to erosion during Quaternary times. The isostatic response to erosional unloading is given by the flexure equation (e.g., Watts, 2001):

$$
D \nabla^{4} w_{(x, y)}=E_{(x, y)} \rho_{c}-\rho_{m} g w_{(x, y)}
$$

where $x$ and $y$ are the horizontal spatial coordinates, $w$ is the isostatic deflection, $E$ is the amount of eroded material, $\rho_{\mathrm{c}}\left(2800 \mathrm{~kg} \mathrm{~m}^{-3}\right)$ and $\rho_{\mathrm{m}}\left(3300 \mathrm{~kg} \mathrm{~m}^{-3}\right)$ are the crustal and mantle densities, respectively, and $g\left(9.8 \mathrm{~m} \mathrm{~s}^{-2}\right)$ is the acceleration of gravity (values in parentheses are those used here). $D$ is the flexural rigidity of the lithosphere, defined as:

$$
D=\frac{Y T_{e}^{3}}{12\left(1-v^{2}\right)}
$$

in which $Y$ is Young's modulus $\left(10^{11} \mathrm{~N} \mathrm{~m}^{-2}\right), T_{e}$ is the equivalent elastic thickness of the lithosphere, and $v$ is Poisson's ratio (0.25). For two-dimensional flexure of an elastic plate with constant elastic thickness, equation (2) can be solved in the frequency domain (Nunn and Aires, 1988; Watts, 2001):

$$
w_{(k)}=\frac{\rho_{C} E_{(k)}}{\rho_{m} g(1+C)}
$$

where $k$ is the wavenumber, $C=D k^{4} / \rho_{\mathrm{m}}$, and other notations are as in Equation (2). Thus, the isostatic response can be calculating by solving (4) after Fourier transforming the spatial load distribution $\left(E_{(x, y)} \rightarrow E_{(k)}\right)$, followed by inverse Fourier transforming the deflection $\left(w_{(k)}\right.$ $\left.\rightarrow w_{(x, y)}\right)$.

The principal unknown in estimating the amount of isostatic rebound is the value of the flexural rigidity (or equivalent elastic thickness) of the lithosphere. Flexural models for the 
Molasse foreland basin in Switzerland (e.g., Burkhard and Sommaruga, 1998; Pfiffner et al., 2002) have come up with widely varying equivalent elastic thicknesses between 10 and 35 $\mathrm{km}$. Moreover, these values may be strongly reduced within the core of the orogen, due to both crustal thickening and large bending stresses (Burov and Diament, 1995; Lyon-Caen and Molnar, 1989). In Figure 12, we show calculated spatial distributions of isostatic rebound across the massifs for equivalent elastic thicknesses of 3,10 , and $30 \mathrm{~km}$. For an extremely low value of flexural rigidity $\left(T_{e}=3 \mathrm{~km}\right)$, the isostatic response to erosion is nearly local, leading to strong rebound of the large incised valleys surrounding the massifs, with maximum values of $\sim 700 \mathrm{~m}$ in the west of the study area. For more realistic values of flexural rigidy, isostatic rebound varies more smoothly across the massifs, reaching maximum values of $\sim 400 \mathrm{~m}$ for our preferred $T_{e}$ value of $10 \mathrm{~km}$. Only for large (and probably overestimated) values of the flexural rigidity $\left(T_{e} \geq 30 \mathrm{~km}\right)$ does isostatic rebound become negligeable $(<150 \mathrm{~m}$ throughout the massifs). It thus appears that the isostatic response to glacial erosion is significant in these massifs, and may account for $\sim 10 \%$ of the peak elevations. It is difficult, however, to compare this amount to present-day rock uplift rates as measured by geodetic methods, or even to assess whether isostatic rebound would have led to the uplift of mountain peaks in this area (cf. discussion section below).

\section{Discussion and conclusions}

We have shown that the relief structure of the western Alpine massifs studied here, expressed as the altitudinal dependence of surface area and slopes, shows a strong glacial imprint. Modal elevations lie consistently within the elevation range limited by the present-day ELA and the reconstructed MEG ELA, and coincide with minima in plots of mean slope as a function of elevation (Figure 7). This observation is consistent with the hypothesis that glacial erosion has flattened and enlarged the areas occurring around the ELA, which has varied through Quaternary times between the two limits defined above. Deeply incised valleys of clearly glacial origin occur within the area. We have made a first-order estimate of the amount of material removed from these glacial troughs and the consequent relief production and isostatic response. The amount of valley carving estimated in this way is a maximum value, as it supposes no pre-glacial incision of the valleys. It is, however, reasonably well correlated to the reconstructed maximum glacier thickness of the different drainage basins studied and may be responsible for half of their geophysical relief (Figure 11). Although our inferences thus 
appear internally consistent, we do note that (1) our reconstructed maximum ice surface and glacial trimline excludes some of the high-elevation cirques and is not well-constrained around the edges of the massifs studied, leading to difficulties in estimating minimum ELA values; (2) our method of estimating "glacial" erosion is rather coarse. In fact, we estimate the total amount of valley incision below conspicuous rock shoulders; we are not able to discriminate between the processes (i.e. glacial, fluvial or hillslope erosion) that carved these valleys. Glacial erosion can be argued to dominate this number, however, since glacial conditions temporally dominated the Quaternary period in the alpine massifs.

Our study predicts that the isostatic response to glacial valley carving in the study area may contribute to $\sim 10 \%$ of the total elevation of the studied massifs. Since our method maximises the amount of valley carving attributed to glaciers, this estimate can be regarded as a maximum value. On the other hand, we do not take local glacial overdeepenings that are known to exist into account in our estimate of glacial valley depths and associated isostatic rebound. Although the overdeepenings have been filled with lake deposits, the difference in density between these Recent unconsolidated sediments $\left(\leq 2000 \mathrm{~kg} \mathrm{~m}^{-3}\right)$ and typical upper crustal rocks $\left(2600-2800 \mathrm{~kg} \mathrm{~m}^{-3}\right)$ will contribute to the isostatic response. Moreover, the total isostatic response to glacial erosion will be larger than the numbers presented here, because the response to valley widening around the mean Quaternary ELA should be added to it.

Given the above result, two questions may be posed: firstly, can we expect local surface uplift to have occurred on mountain peaks as a result of glacial relief increase? Secondly, does the isostatic response to valley incision contribute to measured present-day rock uplift rates in the western Alps, which are difficult to explain tectonically, even when taking postglacial rebound into account? These two questions are difficult to answer because they both require knowledge of rates of isostatic rebound, which will be controlled to a first order by the rate of glacial erosion and relief production.

If we assume that we have isolated the total glacial valley incision affecting the study area, erosion and rebound rates can be estimated if we can identify the onset of glaciation in the western Alps. The onset of widespread Northern-Hemisphere glaciations has been dated at $\sim 2.4$ Ma (e.g., Maslin et al., 1998; Raymo, 1994) but there are indications that the Alps may only have become totally glaciated for the first time at around 0.9 Ma (Muttoni et al., 2003 and references therein). 
In order for isostatic rebound to lead to peak uplift, it should outstrip local surface lowering by erosion. We can make an estimate of surface lowering rates by supposing that regional denudation is constant across the massifs and laterally widespread, so that we can use a $2 \mathrm{D}$ analytical solution to equation (2) for a uniform load (e.g., Turcotte and Schubert, 1982) to estimate the isostatic response:

$$
w_{(0)}=\frac{\rho_{c} E}{\rho_{m}}\left[1-e^{\left(-\frac{L}{\alpha}\right)} \cos \left(\frac{L}{\alpha}\right)\right]
$$

where $w_{(0)}$ is the maximum rebound, $L$ the half-width of the load, $\alpha$ the flexural parameter $(\alpha$ $\left.=\left[4 D / \rho_{\mathrm{c}} g\right]^{1 / 4}\right)$ and other notations are as in (2). Assuming a regional denudation rate of 550 $\mathrm{m} \mathrm{My}{ }^{-1}$, as inferred from low-temperature thermochronology data (van der Beek et al., manuscript in preparation) and a 70-km width of the eroded massifs, maximum isostatic rebound as a response to regional denudation will be $375 \mathrm{~m} \mathrm{My}^{-1}$ in the centre of the massifs. Minimum surface lowering of mountain peaks since the onset of glaciation will thus amount to $\sim 160 \mathrm{~m}$ if this onset took place at $900 \mathrm{ka}$, or $\sim 420 \mathrm{~m}$ if glaciations have affected the Alps since 2.4 Ma. Thus, for reasonable equivalent elastic thickness values of the lithosphere, the isostatic response to valley carving is of the same order as peak surface lowering. It is therefore unlikely that isostatic rebound would have led to a significant (i.e., more than a few tens of $\mathrm{m}$ ) increase in peak elevations in the western Alps.

The question of whether present-day rock uplift rates can be partly explained by the isostatic response to erosion is even more difficult to answer because present-day isostatic uplift, if existent, would by nature be a delayed response to glacial valley carving. At $10^{3}-10^{4} \mathrm{y}$ timescales, isostatic rebound rates are controlled by the viscosity of the asthenosphere. Therefore, a better temporal resolution of the valley carving, as well as a quantification of post-glacial valley incision rates by fluvial processes are required to answer this question. A study of the spatial and temporal variation of erosion rates within the massifs, using cosmogenic isotope data, would allow obtaining such rates.

Finally, an interesting question arises concerning the pre-glacial topography and the timing of major valley incision. If we accept that the pre-glacial landscape did not contain the deep glacially carved valleys that dominate the modern-day landscape, it would be characterised by 
significantly higher mean elevation and lower relief than the present-day topography. A more quantitative perception of what the pre-glacial valleys looked like may be gained applying the river-profile modelling approach shown in Figure 10 to all the main valleys in the study area. As the efficiency of glacial expansion is promoted by higher mean elevations and lower relief, we may expect that the earliest glaciations had a much wider expanse than the later ones, and may even have constituted ice caps that covered the entire topography. Since the highest peaks do not currently show signs of glacial erosion (this is the criterion on which we reconstructed the maximum glacial surface), these must have been eroded away since. Given the regional erosion rates of several $100 \mathrm{~m} / \mathrm{My}$, we may indeed expect the traces of the earliest glaciations to have been removed. However, the early glaciations may have been particularly efficient in carving out the major glacial valleys and may thus have produced a topography that resembles the present-day early on in the glacial history of the massifs, with subsequent glacial expansions only modifying the relief in detail. Such a scenario has been proposed for the Coast Mountains of British Columbia on the basis of high-resolution thermochronology data (Shuster et al., 2005). Again, cosmogenic isotope data could be used to date the surface exposure of landscape elements such as the high-elevation low-relief surfaces and to assess whether these have been strongly modified during the LGM of whether, in contrast, they have survived more than one glacial cycle (e.g., Li et al., 2005).

\section{Acknowledgements}

This study represent PB's MSc project at Université Joseph Fourier and forms part of a project on Quaternary relief development and denudation rates in the western Alps funded by the INSU-CNRS Reliefs de la Terre programme. We thank Anne Letréguilly for discussions on ELA estimates in the western Alps. Constructive reviews by Audrey Huerta, Mike Oskin and Kelin Whipple significantly improved the manuscript. DEM analyses have been performed using the open-source Generic Mapping Tools package (http://gmt.soest.hawaii.edu/), which was also used to prepare most of the $\begin{array}{llll}\text { figures. } & \text { Terrain } & \text { Analysis } & \text { Systems }\end{array}$ (http://www.sed.manchester.ac.uk/geography/research/tas/) was used for drainage-basin extraction. 


\section{References}

Anderson, R.S., Molnar, P. and Kessler, M.A., 2006. Features of glacial valley profiles simply explained. Journal of Geophysical Research, 111: 10.1029/2005JF000344.

Andrews, J.T., 1972. Glacier power, mass balances, velocities and erosion potential. Zeitschrift für Geomorphologie N.F., Suppl. Bd. 13: 1-17.

Bailly-Maître, M.-C., Montjuvent, G. and Mathoulin, V., 1997. Les quatre anciens lacs de l'Oisans (Alpes françaises du Nord). Revue de Géographie Alpine, 85: 33-52.

Battiau-Queney, Y., 1997. Preservation of old palaeosurfaces in glaciated areas: Examples from the French Western Alps. In: M. Widdowson (Editor), Palaeosurfaces: Recognition, reconstruction and palaeoenvironmental interpretation. Geological Society Special Publication 120, London, pp. 125-132.

Beaudevin, C., 2000. Contribution à l'étude de l'altitude atteinte par les glaciers quaternaires dans quelques vallées alpines. Géologie Alpine, 76: 83-116.

Benn, D.I. and Lehmkuhl, F., 2000. Mass balance and equilibrium-line altitudes of glaciers in highmountain environments. Quaternary International, 65-66: 15-29.

Bigot-Cormier, F., Poupeau, G. and Sosson, M., 2000. Dénudations différentielles du massif cristallin externe alpin de l'Argentera (Sud-Est de la France) révélées par thermochronologie traces de fission (apatites, zircons). Comptes Rendus de l'Académie de Sciences de Paris, 330: 363-370.

Brocard, G., 2002. Origine, variabilité spatio-temporelle et signature morphologique de l'incision fluviatile dans les Alpes dauphinoises (SE France), Université Joseph Fourier, Grenoble, $165 \mathrm{pp}$.

Brocard, G.Y. and van der Beek, P.A., 2006. Influence of incision rate, rock strength and bedload supply on bedrock river gradients and valley-flat widths: Field-based evidence and calibrations from western Alpine rivers (SE France). In: S.D. Willett, N. Hovius, M.T. Brandon and D. Fisher (Editors), Tectonics, Climate and Landscape Evolution. Geological Society of America Special Publication, pp. 101-126.

Brocard, G.Y., van der Beek, P.A., Bourlès, D.L., Siame, L.L. and Mugnier, J.-L., 2003. Long-term fluvial incision rates and postglacial river relaxation time in the French Western Alps from 10Be dating of alluvial terraces with assessment of inheritance, soil development and wind ablation effects. Earth and Planetary Science Letters, 209: 197-214.

Brocklehurst, S.H. and Whipple, K.X., 2002. Glacial erosion and relief production in the Eastern Sierra Nevada, California. Geomorphology, 42: 1-24.

Brocklehurst, S.H. and Whipple, K.X., 2003. Hypsometry of glaciated landscapes. Earth Surface Processes and Landforms, 29: 907 - 926.

Brook, M.S., Kirkbride, M.P. and Brock, B.W., 2006. Quantified time scale for glacial valley crossprofile evolution in alpine mountains. Geology, 34: 637-640.

Brozovic, N., Burbank, D.W. and Meigs, A.J., 1997. Climatic limits on landscape development in the northwestern Himalaya. Science, 276: 571-574.

Burkhard, M. and Sommaruga, A., 1998. Evolution of the western Swiss Molasse basin: structural relations with the Alps and the Jura belt. In: A. Mascle, C. Puigdefäbregas, H.P. Luterbacher and M. Fernàndez (Editors), Cenozoic Foreland Basins of Western Europe. Geological Society Special Publication, pp. 279-298.

Burov, E.B. and Diament, M., 1995. The effective elastic thickness (Te) of continental lithosphere: What does it really mean? (Constraints from rheology, topography and gravity). Journal of Geophysical Research, 100: 3905-3927. 
Calais, E., Nocquet, J.-M., Jouanne, F. and Tardy, M., 2002. Current strain regime in the Western Alps from continuous Global Positioning System measurements, 1996-2001. Geology, 30: 651-654.

Chiron, J.C. and Kerrien, Y., 1979. Carte Géologique de la France 1:250000, Feuille 29 Lyon. Bureau de Recherches Géologiques et Minières, Orléans, France.

Clark, D.H., Clark, M.M. and Gillespie, A.R., 1994. Debris-Covered Glaciers in the Sierra Nevada, California, and Their Implications for Snowline Reconstructions. Quaternary Research, 41: 139-153.

Clauzon, G., 1990. Genèse et évolution du piémont néogène subalpin du Bas-Dauphiné, Université d'Aix-Marseille II, Aix-en-Provence.

Coutterand, S. and Nicoud, G., 2005. Les stades de retrait du glacier de l'Arve entre le verroux de Cluses et l'ombilic de Chamonix au cours du tardiglaciaire (Vallée de l'Arve, Haute Savoie). Quaternaire, 16: 82-94.

de Beaulieu, J.-L. and Reille, M., 1984. A long upper-pleistocene pollen record from les Echets near Lyon, France. Boreas, 13: 111-132.

de Martonne, E., 1910-1911. L'érosion glaciaire et la formation des vallées alpines. Annales de Géographie, 19, 20: 289-317, 1-29.

Dumont, T., Champagnac, J.D., Crouzet, C. and Rochat, P., 2006. Multistage Alpine shortening in Central Dauphiné (French Western Alps): implications for pre-Alpine restoration. Tectonophysics, in press.

Florineth, D. and Schlüchter, C., 1998. Reconstructing the last Glacial Maximum (LGM) ice surface geometry and flowlines in the Central Swiss Alps. Eclogae geologicae Helvetiae, 91: 391-407.

Ford, M., 1996. Kinematics and geometry of early alpine, basement-involved folds, SW Pelvoux Massif, SE France. Eclogae geologicae Helvetiae, 89: 269-295.

Gidon, M., 1992. Le Voironnais au Würm II: morphologie et corrélations chronologiques dans le Quaternaire périglaciaire du Bas Dauphiné. Géologie Alpine, 68: 63-75.

Gudmundsson, G.H., 1994. An order-of-magnitude estimate of the current uplift rates in Switzerland caused by the Würm Alpine deglaciation. Eclogae geologicae Helvetiae, 87: 545-557.

Guiter, F. et al., 2005. First evidence of "in situ" Eemian sediments on the high plateau of Evian (Northern Alps, France): implications for the chronology of the Last Glaciation. Quaternary Science Reviews, 24: 35-47.

Haeberli, W. and Penz, U., 1985. An attempt to reconstruct glaciological and climatological characteristics of 18,000 BP ice conditions in and around the Swiss Alps. Zeitschrift für Gletscherkunde und Glazialgeologie, 21: 351-361.

Hallet, B., 1979. A theoretical model of glacial abrasion. Journal of Glaciology, 23: 39-50.

Hallet, B., 1996. Glacial quarrying: A simple theoretical model. Annals of Glaciology, 22: 1-8.

Humphrey, N.F. and Raymond, C.F., 1994. Hydrology, erosion and sediment production in a surging glacier, Variegated Glacier, Alaska, 1982-1983. Journal of Glaciology, 40: 539-552.

Ivy-Ochs, S., Schäfer, J., Kubik, P.W., Synal, H.-A. and Schlüchter, C., 2004. Timing of deglaciation on the northern Alpine foreland (Switzerland). Eclogae Geologicae Helvetiae, 97: 47-55.

Jorda, M., Rosique, T. and Evin, J., 2000. Données nouvelles sur l'âge du dernier maximum glaciaire dans les Alpes méridionales françaises. Comptes Rendus de l'Académie de Sciences, Paris, 331: 187-193.

Jouanne, F., Ménard, G. and Darmendrail, X., 1995. Present-day vertical displacements in the north-western Alps and southern Jura Mountains: Data from levelling comparisons. Tectonics, 14: 606-616. 
Kahle, H.G. et al., 1997. Recent crustal movements, geoid and density distribution: contribution from integrated satellite and terrestrial measurements. In: O.A. Pfiffner, P. Lehner, P. Heitzmann, S. Müller and A. Steck (Editors), Results of the National Research Program 20 (NRP 20). Birkhäuser, Basel, pp. 251-259.

Kelly, M.A., Buoncristiani, J.-F. and Schlüchter, C., 2004. A reconstruction of the last glacial maximum (LGM) ice-surface geometry in the western Swiss Alps and contiguous Alpine regions in Italy and France. Eclogae Geologicae Helvetiae, 97: 57-75.

Kirkbride, M. and Matthews, D., 1997. The role of fluvial and glacial erosion in landscape evolution: The Ben Ohau Range, New Zealand. Earth Surface Processes and Landforms, 22: 317-327.

Kuhlemann, J., Frisch, W., Székely, B., Dunkl, I. and Kázmér, M., 2002. Post-collisional sediment budget history of the Alps: tectonic versus climatic control. International Journal of Earth Sciences, 91: 818-837.

Leloup, P.H., Arnaud, N., Sobel, E.R. and Lacassin, R., 2005. Alpine thermal and structural evolution of the highest external crystalline massif: The Mont Blanc. Tectonics, 24: TC4002, 10.1029/2004TC001676.

$\mathrm{Li}$, Y. et al., 2005. Ice sheet erosion patterns in valley systems in northern Sweden investigated using cosmogenic nuclides. Earth Surface Processes and Landforms, 30: 1039-1049.

Lliboutry, L., 1964. Traité de Glaciologie. Editions Masson, Paris, 1040 pp.

Lyon-Caen, H. and Molnar, P., 1989. Constraints on the deep structure and dynamic processes beneath the Alps and adjacent regions from an analysis of gravity anomalies. Geophysical Journal International, 99: 19-32.

MacGregor, K.R., Anderson, R.S., Anderson, S.P. and Waddington, E.D., 2000. Numerical simulations of glacial-valley longitudinal profile evolution. Geology, 28: 1071-1074.

Maslin, M.A., Li, X.S., Loutre, M.F. and Berger, A., 1998. The contribution of orbital forcing to the progressive intensification of northern hemisphere glaciation. Quaternary Science Reviews, 17: 411-426.

Meigs, A. and Sauber, J., 2000. Southern Alaska as an example of the long-term consequences of mountain building under the influence of glaciers. Quaternary Science Reviews, 19: 15431562.

Métivier, F., Gaudemer, Y., Tapponier, P. and Klein, M., 1999. Mass accumulation rates in Asia during the Cenozoic. Geophysical Journal International, 137: 280-318.

Michalski, I. and Soom, M., 1990. The Alpine thermo-tectonic evolution of the Aar and Gotthard massifs, central Switzerland: Fission track ages on zircon and apatite and K-Ar mica ages. Schweizerische Mineralogische und Petrografische Mitteilungen, 70: 373-387.

Molnar, P., 2004. Late Cenozoic increase in accumulation rates of terrestrial sediment: How might climate change have affected erosion rates? Annual Review of Earth and Planetary Sciences, 32: 67-89.

Molnar, P. and England, P., 1990. Late Cenozoic uplift of mountain ranges and global climate change: chicken or egg? Nature, 346: 29-34.

Montgomery, D.R., 1994. Valley incision and the uplift of mountain peaks. Journal of Geophysical Research, 99: 13913-13921.

Montgomery, D.R., 2002. Valley formation by fluvial and glacial erosion. Geology, 30: 1047-1050.

Montjuvent, G., 1974. Considérations sur le relief glaciaire à propos des Alpes du Dauphiné. Revue de Géographie Physique et de Géologie Dynamique, 16: 465-502.

Montjuvent, G., 1978. Le Drac. Morphologie, stratigraphie et chronologie quaternaires d'un bassin alpin. Editions du CNRS. Comité National de la Recherche Scientifique, Paris, 433 pp.

Montjuvent, G. and Winistorfer, J., 1980. Glaciations quaternaires dans les Alpes franco-suisses et leur piédmont. Géologie Alpine, 56: 251-282.

Muttoni, G. et al., 2003. Onset of major Pleistocene glaciations in the Alps. Geology, 31: 989-992. 
Nunn, J.A. and Aires, J.R., 1988. Gravity Anomalies and flexure of the lithosphere at the middle Amazon Basin, Brazil. Journal of Geophysical Research, 93: 415-428.

Oskin, M. and Burbank, D.W., 2005. Alpine landscape evolution dominated by cirque retreat. Geology, 33: 933-936.

Penck, A. and Brückner, F., 1901-1909. Die Alpen im Eiszeitalter. Tauchnitz, Leipzig, 1199 pp.

Peysson, E., 2000. Age et modalités de la formation du relief du massif du Pelvoux : Influences tectoniques et climatiques. MSc Thesis, Université Joseph Fourier, Grenoble, 34 pp.

Pfiffner, O.A., Schlunegger, F. and Buiter, S.J.H., 2002. The Swiss Alps and their peripheral foreland basin: Stratigraphic response to deep crustal processes. Tectonics, 21: 10.1029/2000TC900039.

Porter, S.C., 1989. Some geological implications of average Quaternary glacial conditions. Quaternary Research, 32: 245-261.

Porter, S.C., 2000. Snowline depression in the tropics during the Last Glaciation. Quaternary Science Reviews, 20: 1067-1091.

Rabatel, A., Dedieu, J.-P. and Vincent, C., 2005. Using remote-sensing data to determine equilibrium-line altitudes and mass-balance time series: validation on three French glaciers, 1994-2002. Journal of Glaciology, 51: 539-546.

Ramage, J.M., Smith, J.A., Rodbell, D.T. and Seltzer, G.O., 2005. Comparing reconstructed Pleistocene equilibrium-line altitudes in the tropical Andes of central Peru. Journal of Quaternary Science, 20: 777-788.

Raymo, M.E., 1994. The Initiation of Northern Hemisphere Glaciation. Annual Review of Earth and Planetary Sciences, 22: 353-383.

Raymo, M.W. and Ruddiman, W.F., 1992. Tectonic forcing of late Cenozoic climate. Nature, 359: 117-122.

Schlüchter, C., 1986. The Quaternary glaciations of Switzerland, with special reference to the northern Alpine Foreland. Quaternary Science Reviews, 5: 413-419.

Schlüchter, C., 1988. The deglaciation of the Swiss Alps: A paleoclimate event with chronological problems. Bulletin de l'Association Française pour l'Etude du Quaternaire, 2/3: 141-145.

Schmid, S.M. and Kissling, E., 2000. The arc of the western Alps in the light of geophysical data on deep crustal structure. Tectonics, 19: 62-85.

Schoeneich, P., 1998. Corrélation du dernier maximum glaciaire et de la déglaciation alpine avec l'enregistrement isotopique du Groënland. Quaternaire 9: 203-215.

Shuster, D.L., Ehlers, T.A., Rusmore, M.E. and Farley, K.A., 2005. Rapid glacial erosion at $1.8 \mathrm{Ma}$ revealed by $4 \mathrm{He} / 3 \mathrm{He}$ thermochronometry. Science, 310: 1668-1670.

Small, E. and Anderson, R.S., 1995. Geomorphically driven late Cenozoic rock uplift in the Sierra Nevada, California. Science, 270: 277-280.

Small, E. and Anderson, R.S., 1998. Pleistocene relief production in Laramide mountain ranges, western Unites States. Geology, 26: 123-126.

Smith, W.H.F. and Wessel, P., 1990. Gridding with continuous curvature splines in tension. Geophysics, 55: 293-305.

Spotila, J.A., Buscher, J.T., Meigs, A.J. and Reiners, P.W., 2004. Long-term glacial erosion of active mountain belts: Example of the Chugach-St. Elias Range, Alaska. Geology, 32: 501504.

Stern, T.A., Baxter, A.K. and Barrett, P.J., 2005. Isostatic rebound due to glacial erosion within the Transantarctic Mountains. Geology, 33: 221-224.

Stocchi, P., Spada, G. and Cianetti, S., 2005. Isostatic rebound following the Alpine deglaciation: impact on the sea level variations and vertical movements in the Mediterranean region. Geophysical Journal International, 162: 137-147.

Tomkin, J.H. and Braun, J., 2002. The influence of alpine glaciation on the relief of tectonically active mountain belts. American Journal of Science, 302: 169-190. 
Tricart, J. and Cailleux, A., 1962. Le modelé glaciaire et nival. Traité de Géomorphologie, 3. Ed. Sedes, Paris, 508 pp.

Turcotte, D.L. and Schubert, G., 1982. Geodynamics, Applications of continuum physics to geological problems. John Wiley and sons, New York, 450 pp.

Vincent, C., 2002. Influence of climate change over the 20th Century on four French glacier mass balances. Journal of Geophysical Research, 107: 4375, doi:10.1029/2001JD000832.

Watts, A.B., 2001. Isostasy and Flexure of the Lithosphere. Cambridge University Press, Cambridge, U.K., 458 pp.

Whipple, K.X., Kirby, E. and Brocklehurst, S.H., 1999. Geomorphic limits to climate-induced increases in topographic relief. Nature, 401: 39-43.

Zhang, P., Molnar, P. and Downs, W.R., 2001. Increased sedimentation rates and grain sizes 2-4 Myr ago due to the influence of climate change on erosion rates. Nature, 410: 891-897. 


\section{FIGURE CAPTIONS}

Fig. 1. Digital Elevation Model of the study area based on Institut Géographique National 50-m resolution digital topography data, with boundaries of different catchments studied (Li: Lignarre; Sa: Sarenne; Se: Severaisette; BO: Bourg d'Oisans valley; Ch: Chartreuse Massif; V: Vercors Massif). Eastings and northings are according to the IGN Lambert-III grid, in kilometres. Inset shows location within France.

Fig. 2. Field photos showing high-elevation, low relief surfaces deeply incised by glacially scoured valleys. (a) Aerial view of the Bourg d'Oisans valley and surrounding areas, looking toward SE. (b) View toward ENE from the Taillefer lakes across the Bourg d'Oisans valley to the Grandes Rousses Massif. Incised valley in background is Sarenne. For location of landscape elements shown in these photos, see Figures 1 and 3.

Fig. 3. Slope map of the central part of the study area. Eastings and northings as in Figure 1. Cross patterns indicates extent of basement outcrop. Low-gradient areas are either glacially scoured (and lake-filled) valley bottoms (BO: Bourg d'Oisans plain; G: Grésivaudan; MA: Matheysine plateau) or high-elevation plateaux (AH: Alpe d'Huez, 2000 m. elev.; CC: Croix de Chamrousse, 1500-2300 m elev.; E: Emparis plateau, 2500 m elev.; ML: Mont de Lans plateau, 3100-3500 m elev.; T: Taillefer lakes plateau, 2050-2300 m elev.).

Fig. 4. Slope distributions for several characteristic lithologies of the study area (in black: basement rocks; in grey: sedimentary cover rocks). Modal slope values are generally higher in basement rocks than in sedimentary cover, particularly within the granites, amphibolites and meta-conglomerates that characterise the Pelvoux-Ecrins and Grandes Rousses, eastern Belledonne, and Taillefer massifs, respectively. Modified from Peysson (2000).

Fig. 5. Distribution and elevation of geomorphic features used to reconstruct the maximum glacial extent in the study area. Box outlines the area for which we show the reconstructed glacial surface in Figure 6. Only the highest-elevation features at any locality are used and the glacial surface is supposed to pass through the summits of moraines, $50 \mathrm{~m}$ above glacial grooves associated with drumlin-like features and 
roches moutonnées, and $100 \mathrm{~m}$ above glacial erosion grooves in rock shoulders. See text for discussion.

Fig. 6. (a) Reconstructed ice surface with elevation contours; peaks exceeding the trimline (nunataks) are shown with the elevation scale as in Figure 1. (b) Reconstructed ice thickness and inferred position of MEG ELA (thick black line, see text for discussion). Eastings and northings as in Figure 1.

Fig. 7. Hypsometry and altitudinal dependence of slopes for the different drainage basins studied. Elevation frequency data (grey lines) have been binned in 100-m intervals; for each interval, the mean slope angle (black lines; calculated as the scalar value of the first derivative of elevation) is plotted. Thick black line on right of each graph is present-day ELA $(2900 \mathrm{~m})$, shaded bar on left is inferred position of MEG ELA (1700-1900 m). See text for discussion.

Fig. 8. Conceptual sketch of our approach to estimate glacial valley depths and the potential errors involved in the approach. We extract high-elevation, low-relief (HE-LR) surfaces from the DEM and interpolate between these. Extracting the present-day topography from the interpolated surface leads to an estimate of glacial valley carving. The method does not take into account glacial valley widening (which has led to the HE-LR surfaces), pre-glacial valley incision or local glacial overdeepening (not shown).

Fig. 9. Estimate of glacial valley carving: (a) Extracted high-elevation, low-relief (HE-LR) surfaces - these were isolated from the DEM by applying a spatially varying minimum elevation threshold as well as a maximum slope threshold. Lines ABC and DE correspond to the two topographic profiles shown in (c) and (d), respectively; (b) Inferred glacial valley depths, obtained by subtracting present-day topography from an interpolated surface passing through the data in (a). Thick black line is inferred position of minimum ELA at $\sim 1800 \mathrm{~m}$ elevation; (c) and (d) elevation profiles across the Lower and Upper Romanche River, respectively, showing relationships between present-day topography, interpolated surface and extracted HE-LR surfaces, as well as estimated amount of valley incision. Extracted HE-LR surfaces have been projected onto the profile from a 1-km wide swath 
centred on it. Abbreviations: CC: Croix de Chamrousse plateau; BO: Bourg d'Oisans.

Fig. 10. Present-day and reconstructed pre-glacial long profiles of the Romanche River and its downstream continuation in the Drac and Isère rivers. The present-day profile is extracted from the digital elevation model; the pre-glacial profile is modelled assuming that it can be described by a stream power law $S=k_{s} A^{-\theta}$, with $k_{s}=20$ and $\theta=0.36$. The pre-glacial profile is fixed at the downstream confluence of the Isère and the Rhone rivers; it is compared to the elevation of the high-elevation low-relief (HE-LR) surfaces, as well as to the surface of the fluvial deposits of the Chambaran plateau. Inset shows slope-area plots for the present-day Romanche River as well as for the non-glacial equilibrium Buëch and Drôme rivers to the SW of the study area. Continuous line represents the model stream-power law used to construct the preglacial profile. See text for discussion.

Fig. 11. Reconstructed mean glacial erosion (defined as the sum of glacial valley depths at each pixel in a catchment, divided by catchment area) for the 9 studied catchments as a function of maximum ice cover, maximum ice thickness, and geophysical (subridgeline) relief, respectively (data in Table 1). Size of the circles is proportional to (logarithm of) catchment area. Pearson correlation coefficients $r^{2}$ are given in each plot for all the data, and excluding the three smalles catchments (Sarenne, Lignarre, Séveraissette) in parentheses.

Fig. 12. Estimated flexural isostatic rebound in response to the amount and distribution of glacial valley carving shown in Figure $8 \mathrm{~b}$, and for equivalent elastic thicknesses of the lithosphere of $3 \mathrm{~km}$ (left), $10 \mathrm{~km}$ (centre), and $30 \mathrm{~km}$ (right). Grid of erosion values was reinterpolated on a 500-m resolution grid (144 × 192 nodes), which was centred upon a $512 \times 512$ node grid, with erosion values tapered to the edges, before performing a fast Fourier transform and calculating the isostatic response function. 
Table 1. Characteristics, reconstructed ice cover, inferred glacial erosion and geophysical relief for the studied catchments.

\begin{tabular}{|c|c|c|c|c|c|c|c|c|c|}
\hline $\begin{array}{l}\text { Drainage } \\
\text { basin }\end{array}$ & $\begin{array}{l}\text { Area } \\
\left(\mathrm{km}^{2}\right)\end{array}$ & Min & $\begin{array}{l}\text { Mean } \\
\text { Elevation } \\
\quad(\mathrm{m})\end{array}$ & Max & $\begin{array}{l}\text { Ice } \\
\text { cover } \\
(\%)\end{array}$ & $\begin{array}{l}\text { Mean ice } \\
\text { thickness } \\
\text { (m) }\end{array}$ & $\begin{array}{c}\text { ELA } \\
(\mathrm{THAR}=0.5) \\
(\mathrm{m})\end{array}$ & $\begin{array}{l}\text { Mean } \\
\text { erosion } \\
(\mathrm{m})\end{array}$ & $\begin{array}{c}\text { Mean } \\
\text { Geophys. } \\
\text { Relief (m) }\end{array}$ \\
\hline $\begin{array}{l}\text { Upper } \\
\text { Romanche }\end{array}$ & 362 & 717 & 2225 & 3874 & 60 & 432 & 1850 & 283 & 576 \\
\hline Vénéon & 319 & 715 & 2357 & 4004 & 46 & 472 & 1875 & 398 & 716 \\
\hline Eau d'Olle & 169 & 717 & 1940 & 3433 & 61 & 440 & 1750 & 239 & 450 \\
\hline Sarenne & 36 & 719 & 2043 & 3304 & 61 & 287 & 1700 & 166 & 127 \\
\hline Lignarre & 57 & 712 & 1592 & 2829 & 64 & 533 & 1425 & 515 & 456 \\
\hline Bonne & 431 & 521 & 1620 & 3473 & 57 & 394 & 1700 & 485 & 833 \\
\hline Séveraisse & 221 & 776 & 1949 & 3652 & 54 & 443 & 1700 & 470 & 737 \\
\hline Séveraissette & 64 & 932 & 1844 & 3160 & 30 & 171 & 1650 & 435 & 299 \\
\hline Upper Drac & 201 & 1164 & 2129 & 3419 & 36 & 291 & 1700 & 227 & 532 \\
\hline
\end{tabular}



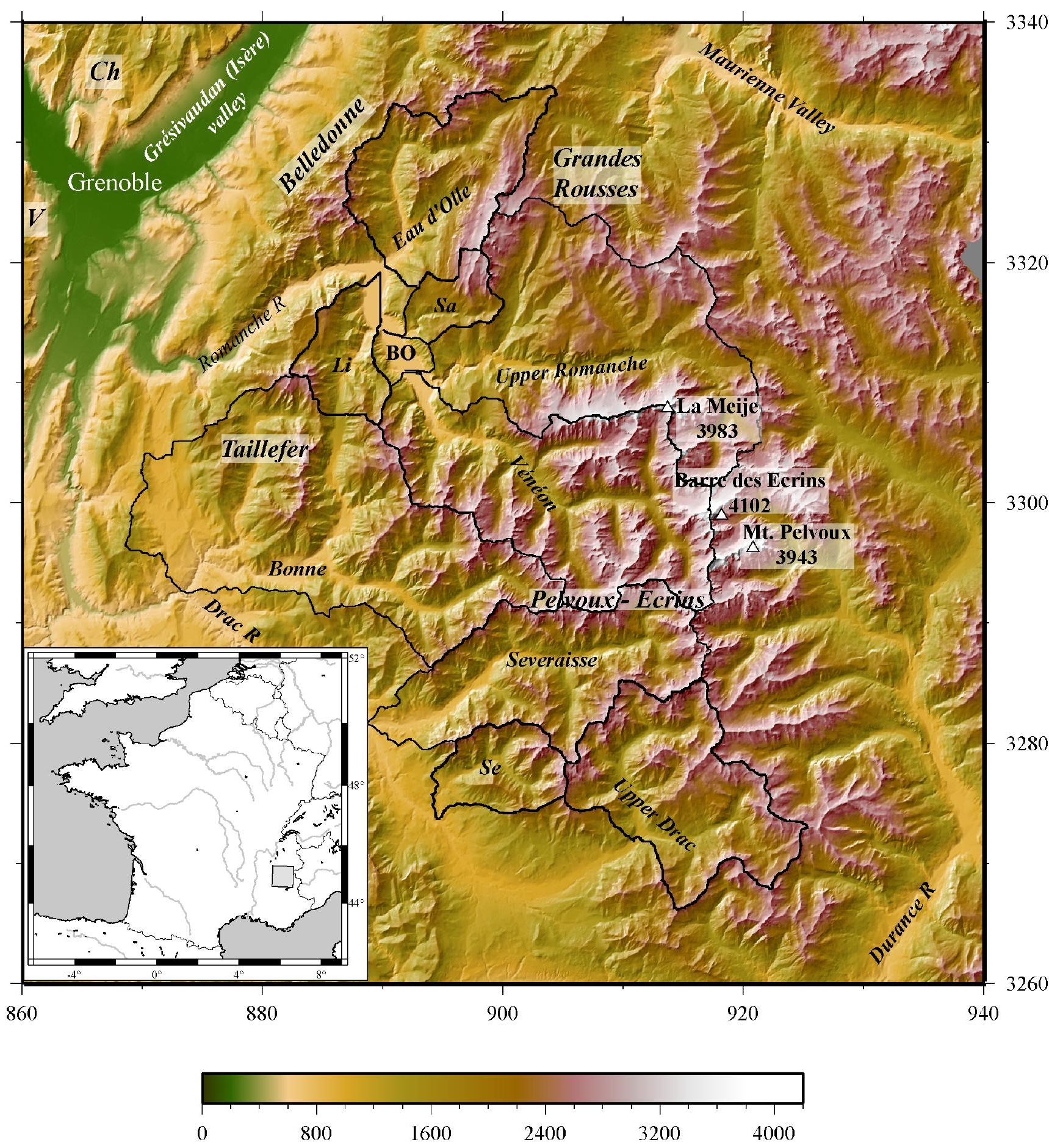

Elevation (m)

van der Beek \& Bourbon Figure 1 


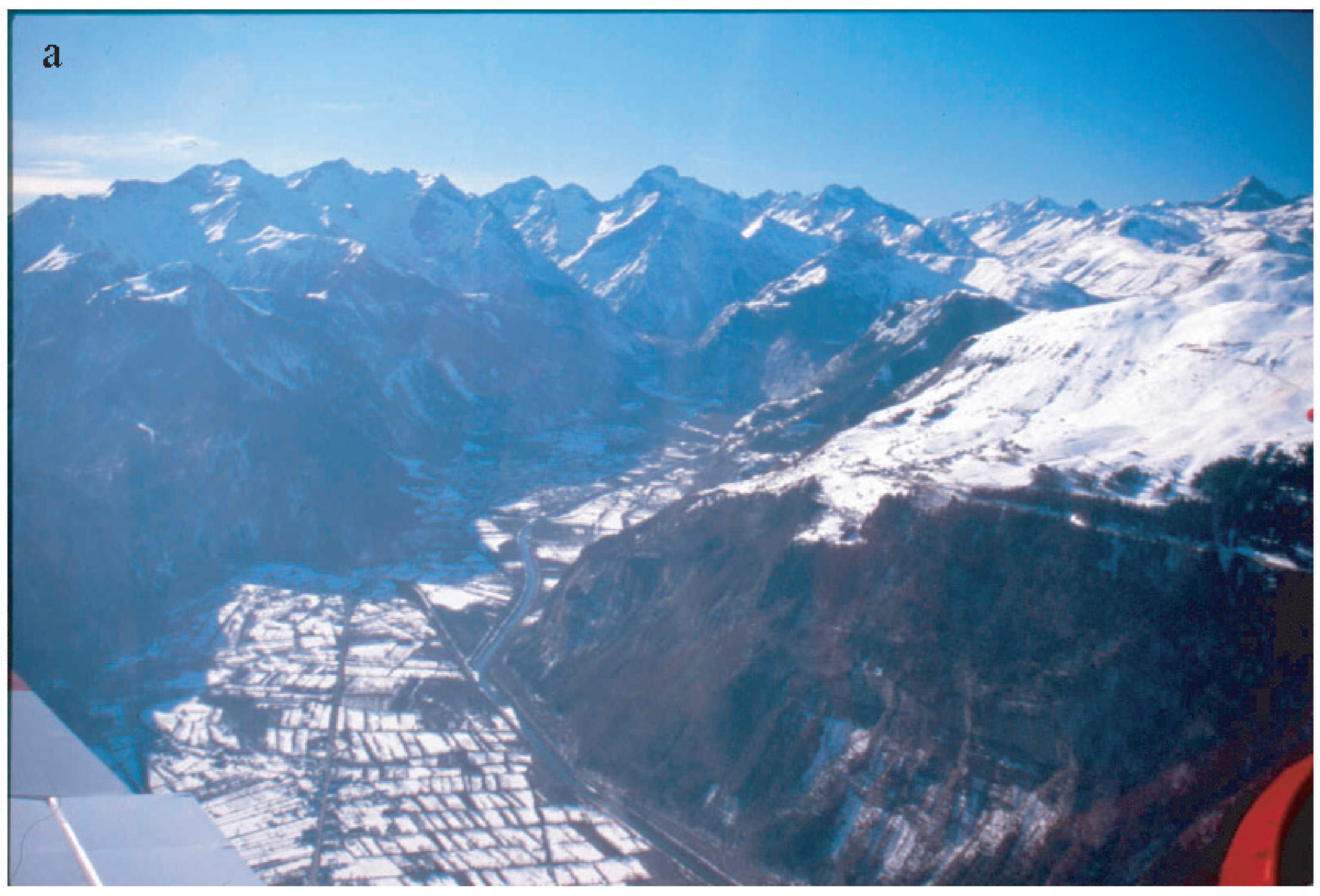

b

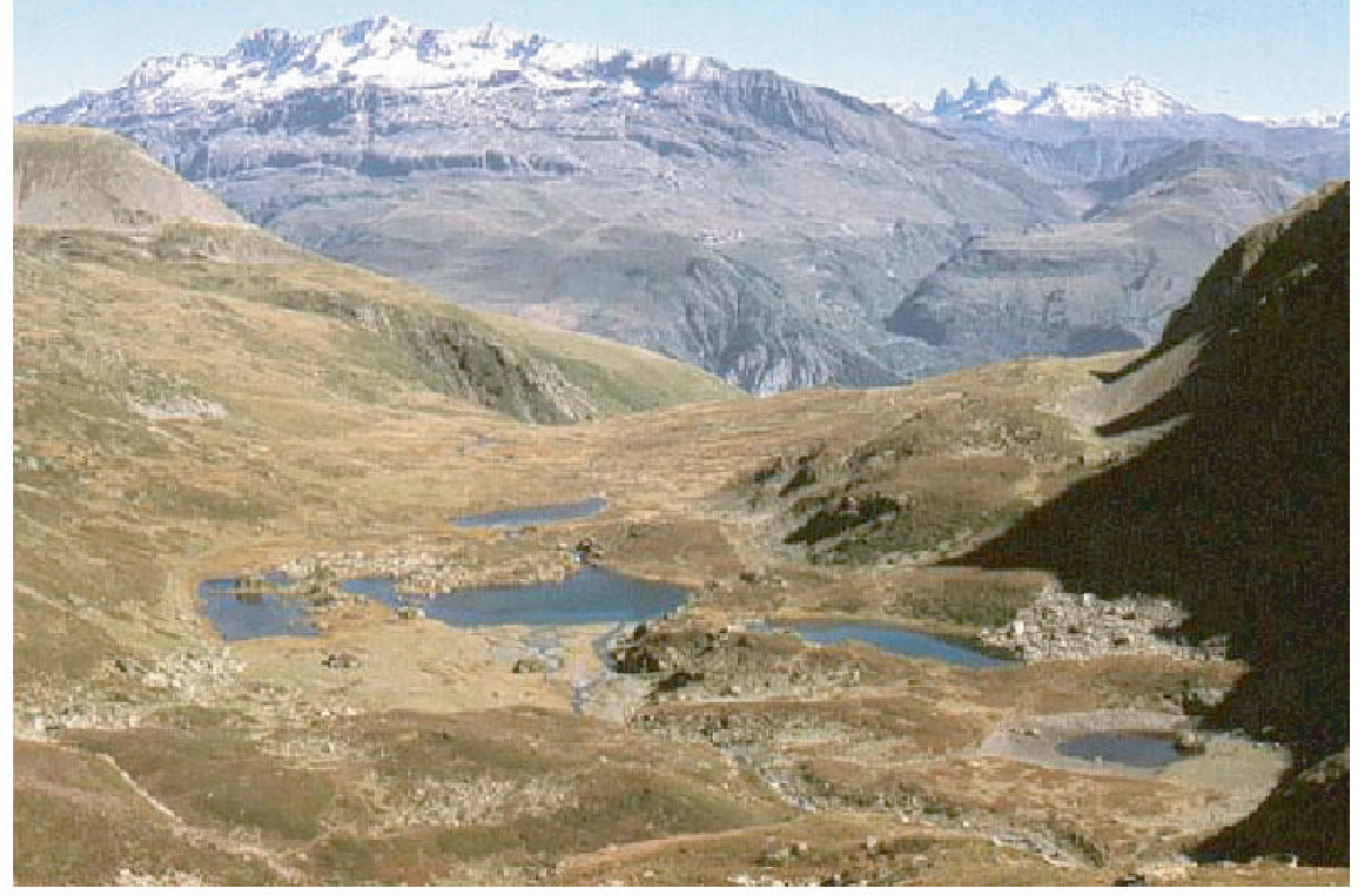

van der Beek \& Bourbon

Figure 2 

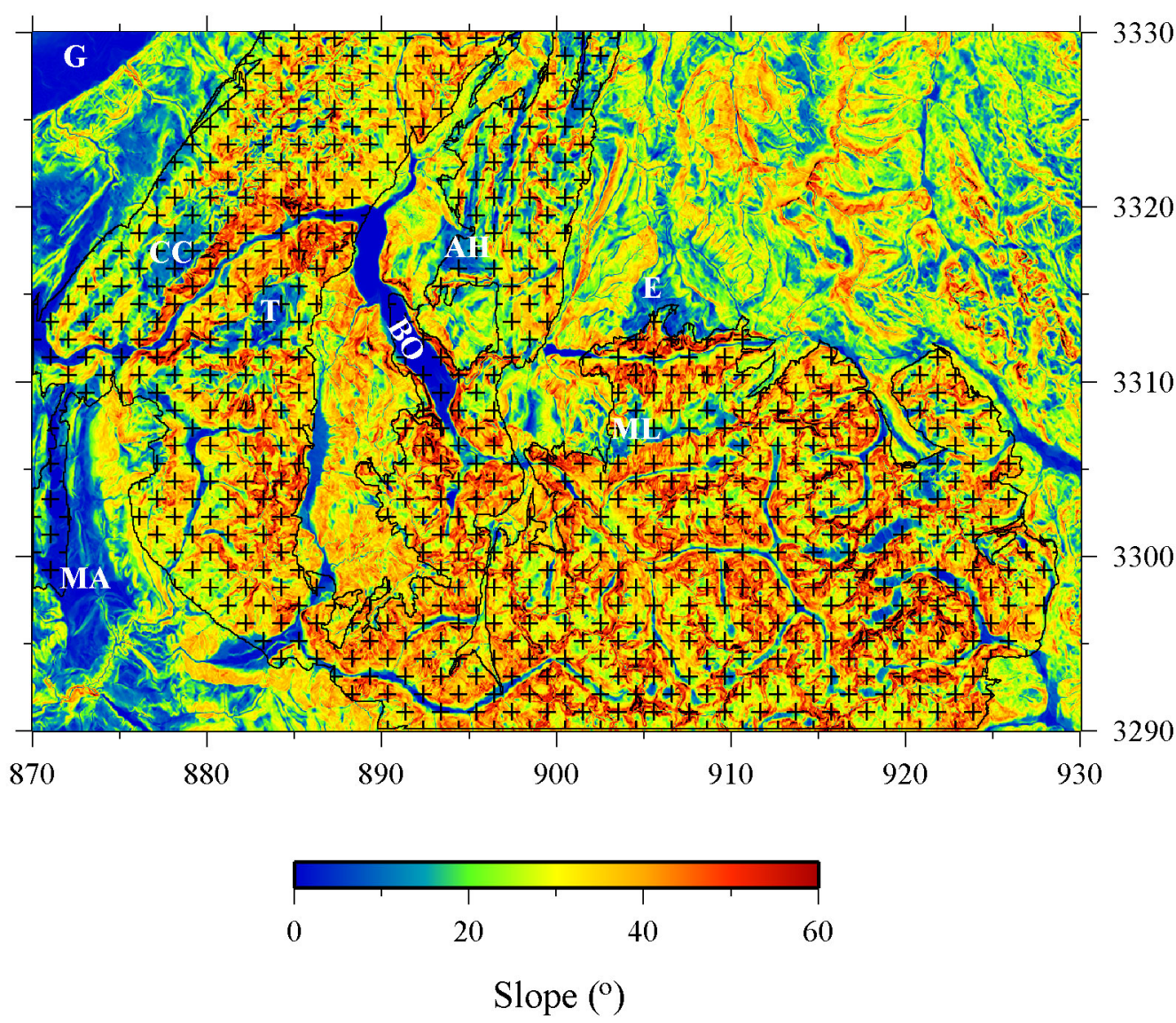

van der Beek \& Bourbon

Figure 3 


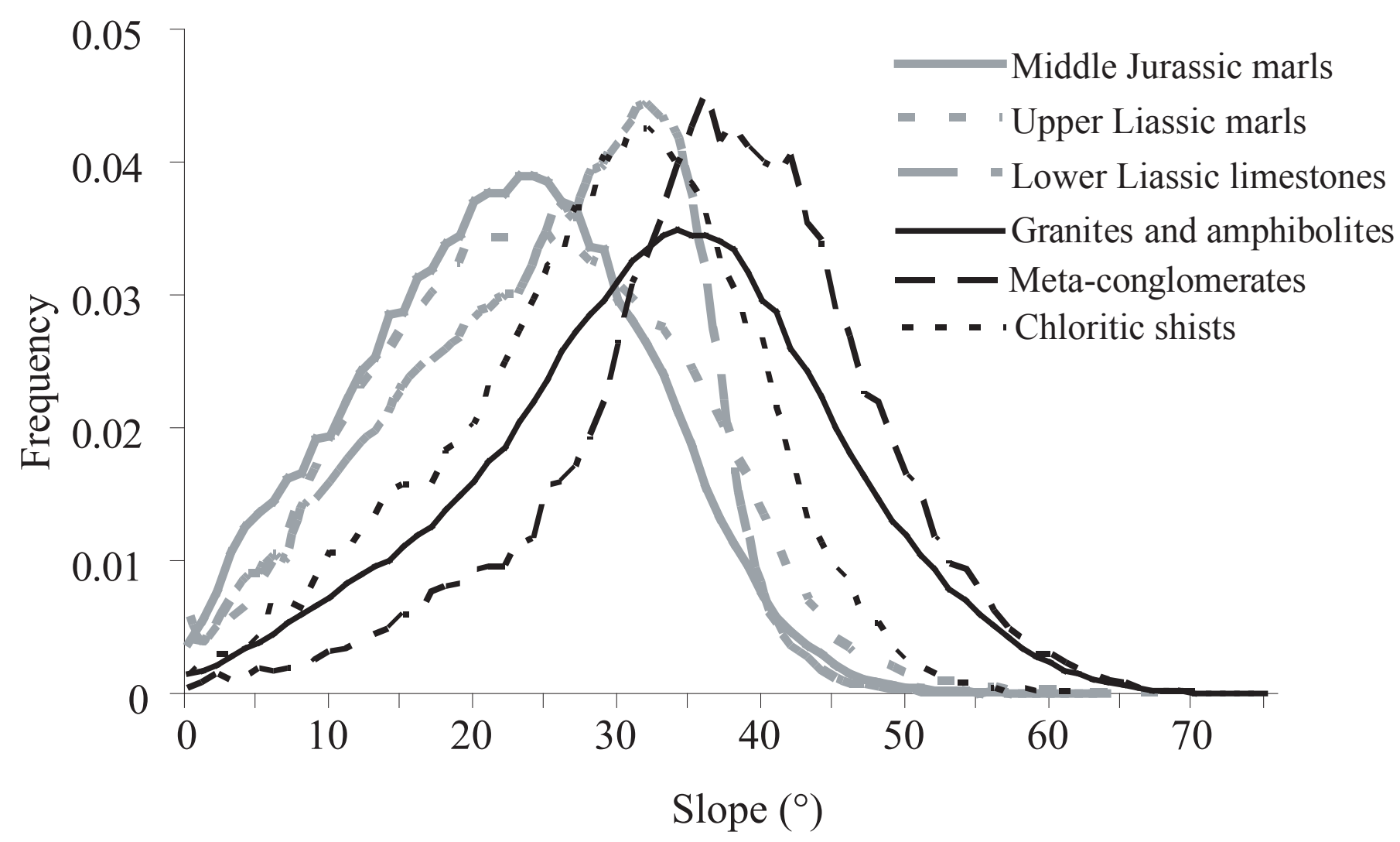

van der Beek \& Bourbon

Figure 4 


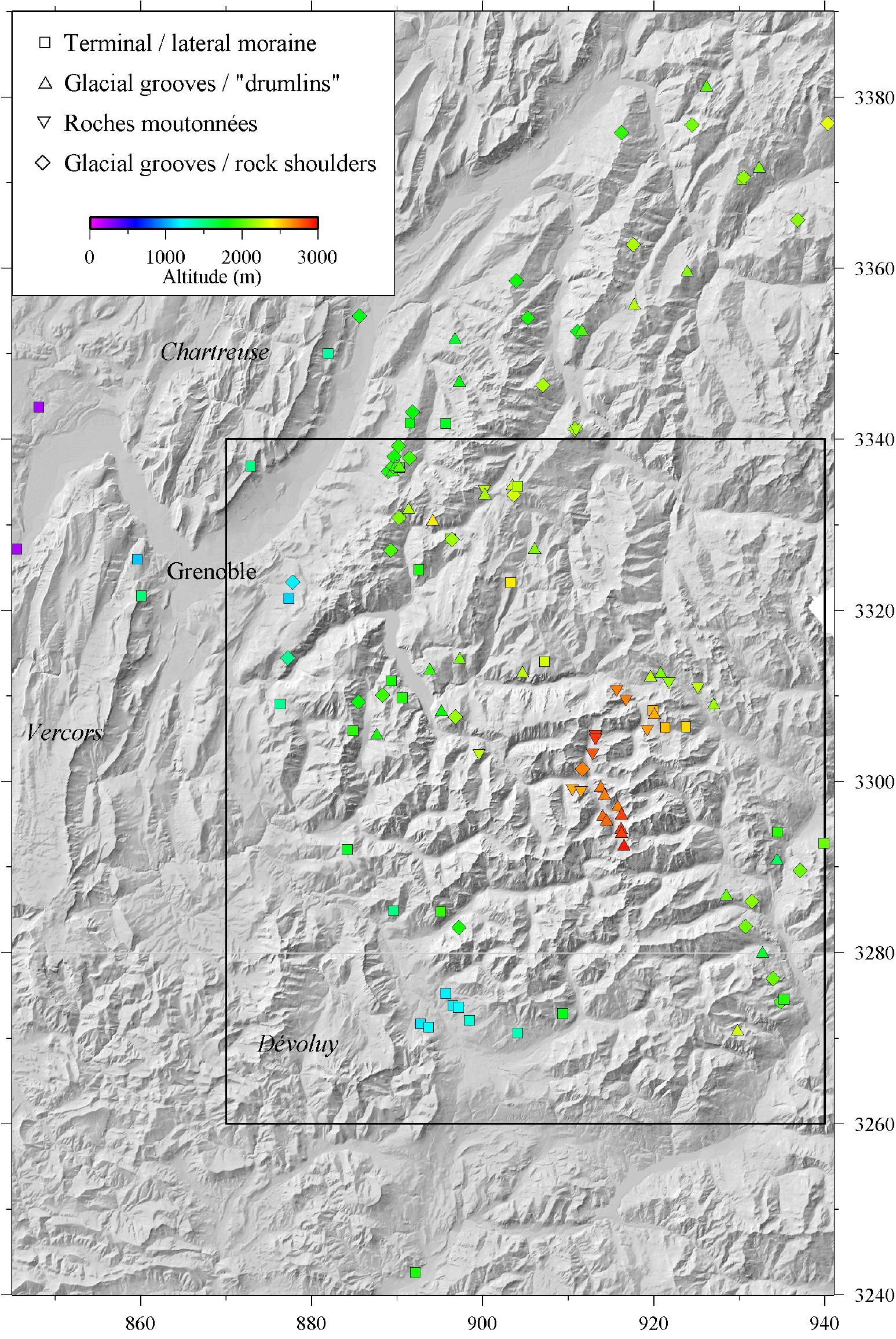

van der Beek \& Bourbon

Figure 5 

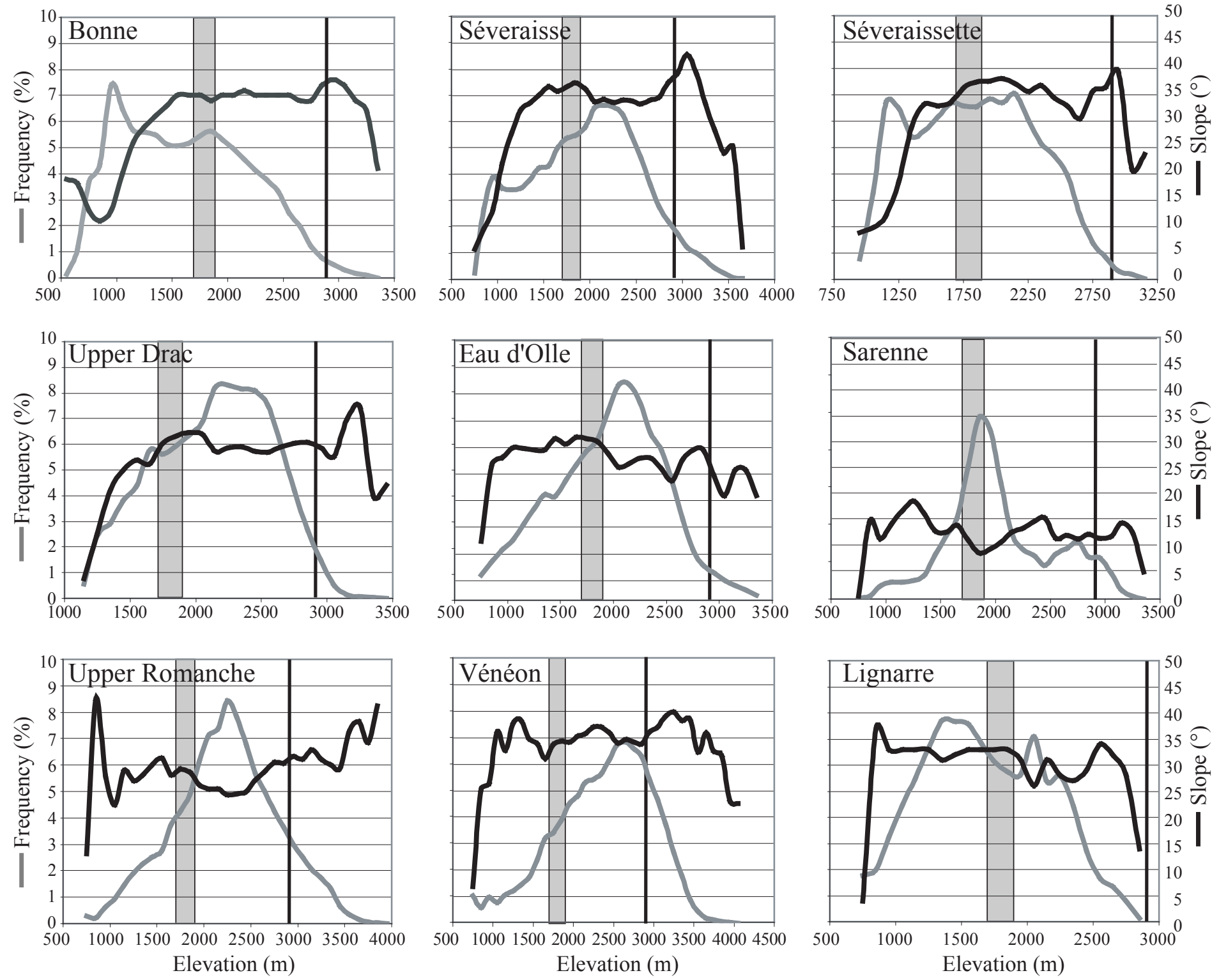

van der Beek \& Bourbon

Figure 7 


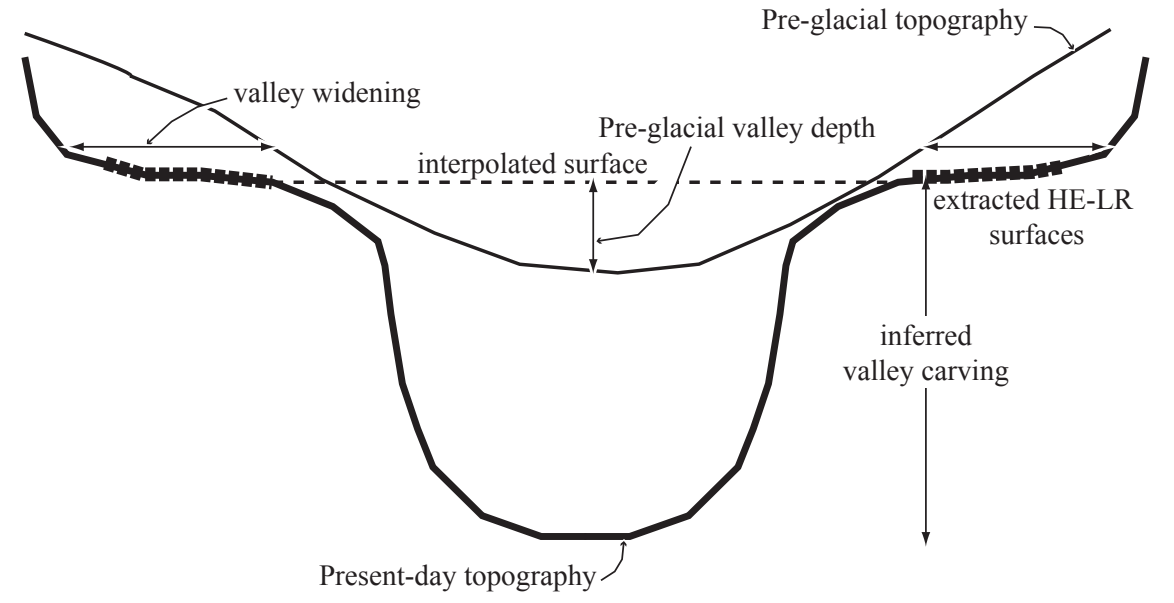

van der Beek \& Bourbon

Figure 8 

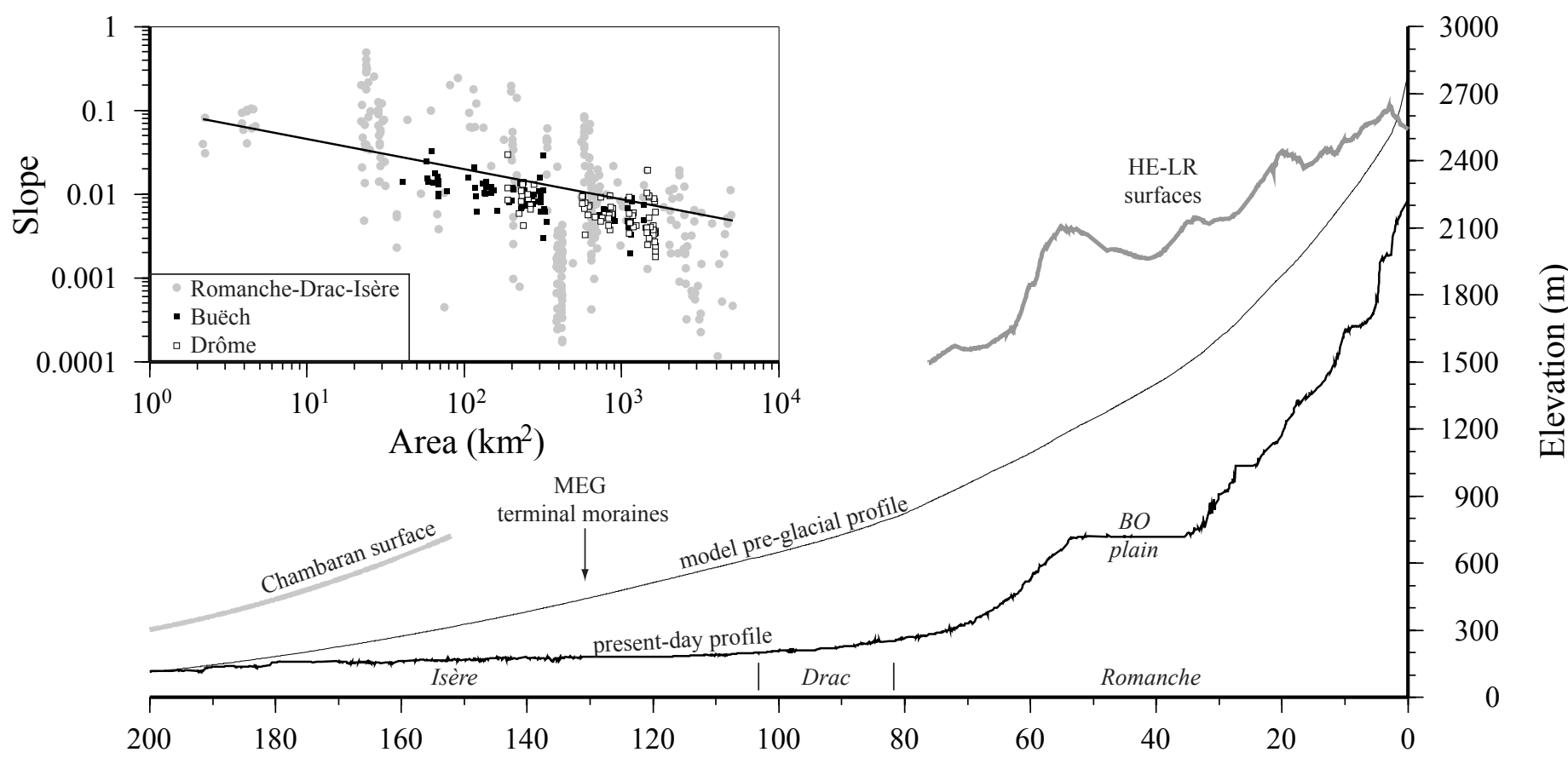

Distance $(\mathrm{km})$

van der Beek \& Bourbon

Figure 10 

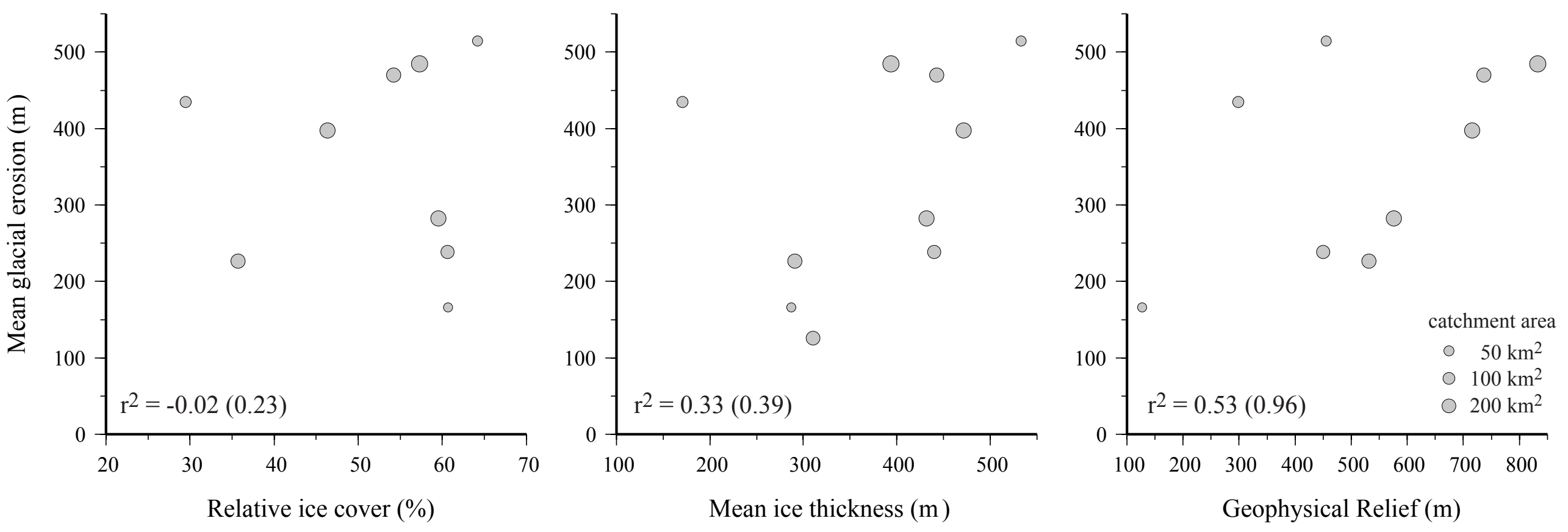

van der Beek \& Bourbon

Figure 11 
$$
T_{e}=3 \mathrm{~km}
$$

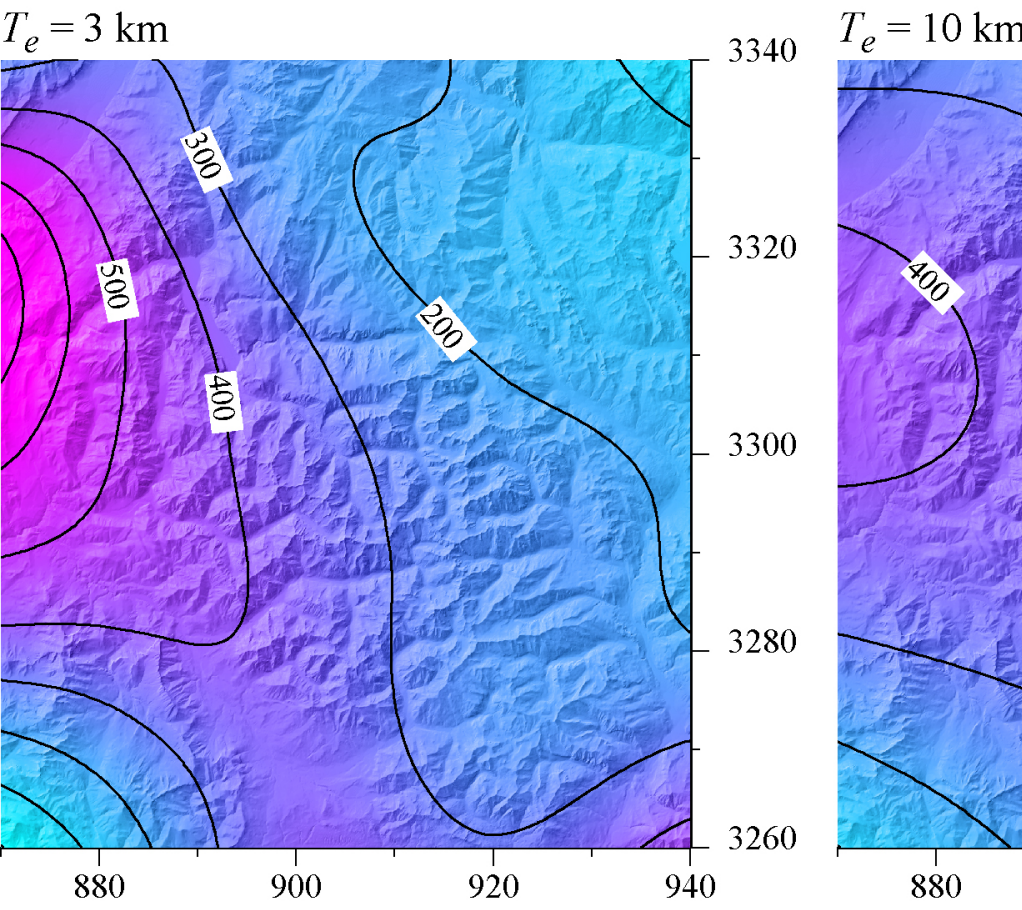

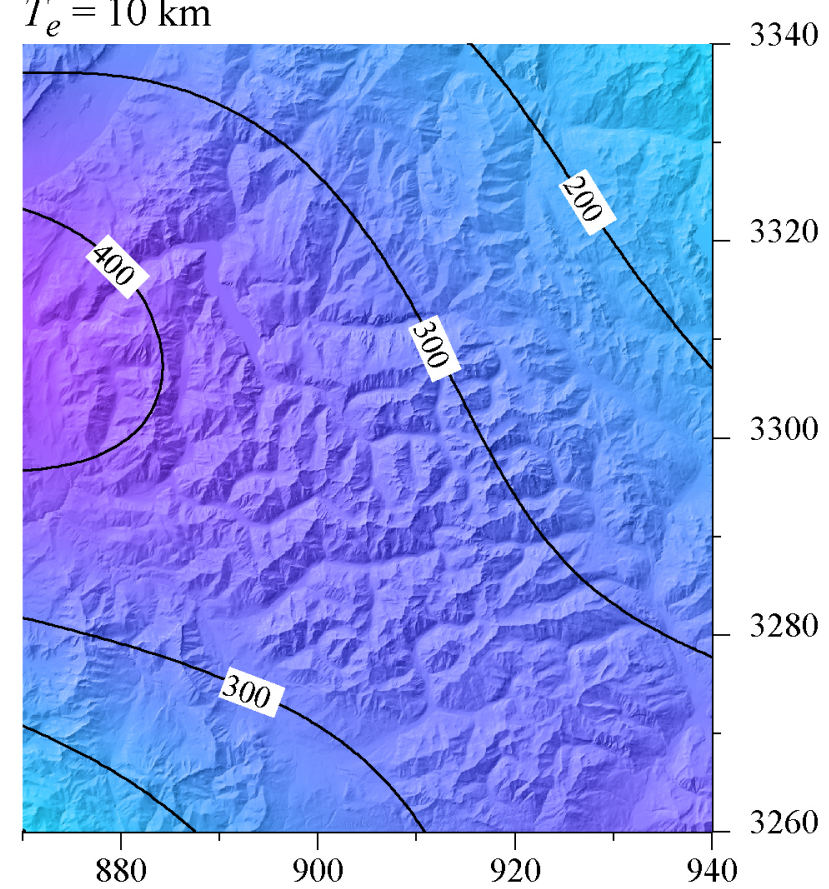

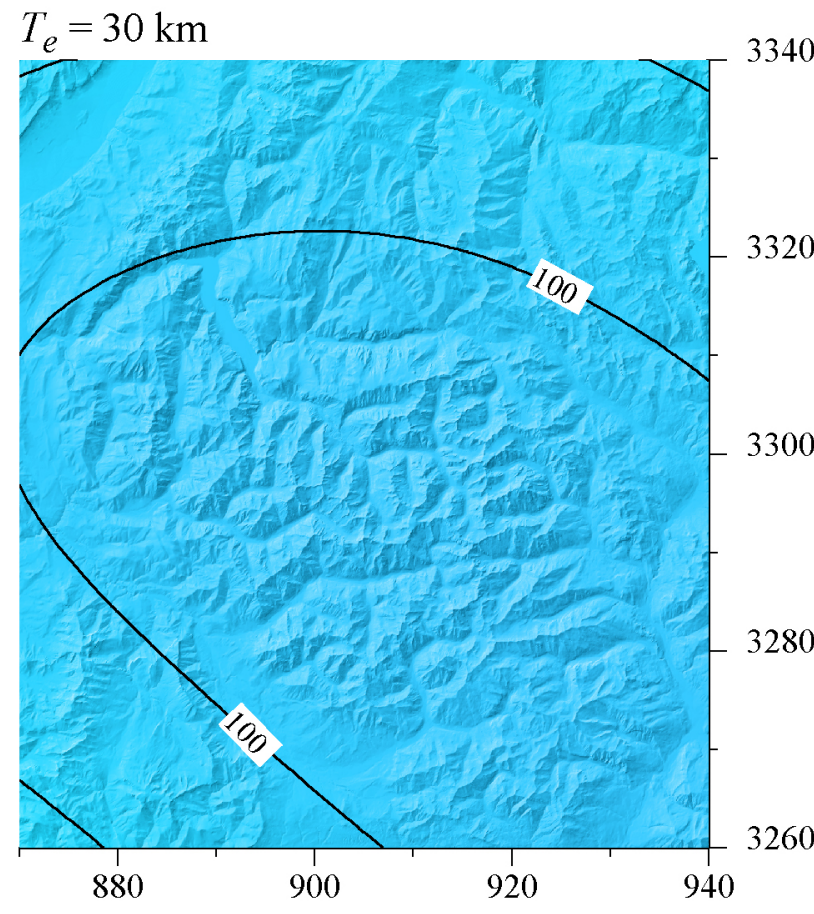

van der Beek \& Bourbon

Figure 12

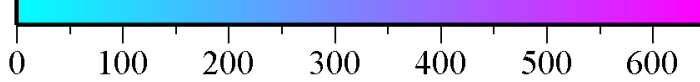

Isostatic rebound (m) 